Article

\title{
Synthesis, Antifungal Activities and Molecular Docking Studies of Benzoxazole and Benzothiazole Derivatives
}

\author{
Bo Luo ${ }^{1,2}$, Ding Li ${ }^{2, * \mathbb{D}}$, An-Ling Zhang ${ }^{2}$ and Jin-Ming Gao ${ }^{2, *}$ \\ 1 College of Life Sciences, Xinyang Normal University, Tea Plant Biology Key Laboratory of Henan Province, \\ Xinyang 464000, China; luobo2011@163.com \\ 2 Shaanxi Key Labotory of Natural Products \& Chemical Biology, Shaanxi Engineering Center of Bioresource \\ Chemistry \& Sustainable Utilization, College of Chemistry \& Pharmacy, Northwest A\&F University, \\ Yangling 712100, China; linganzh@163.com \\ * Correspondence: jbolid@nwsuaf.edu.cn (D.L.); jinminggao@nwsuaf.edu.cn (J.-M.G.); \\ Tel./Fax: +86-29-87092335 (J.-M.G.)
}

Received: 21 August 2018; Accepted: 19 September 2018; Published: 25 September 2018

\begin{abstract}
Based on benzoxazole and benzothiazole scaffold as an important pharmacophore, two series of 2-(aryloxymethyl) benzoxazole and benzothiazole derivatives were synthesized and their antifungal effects against eight phytopathogenic fungi were evaluated. Compounds $\mathbf{5 a}, \mathbf{5} \mathbf{b}, \mathbf{5} \mathbf{h}$, and $\mathbf{5 i}$ exhibited significant antifungal activities against most of the pathogens tested. Especially $\mathbf{5 a}, \mathbf{5} \mathbf{b}, \mathbf{5} \mathbf{h}$, $5 \mathbf{i}, \mathbf{5 j}$, and $\mathbf{6 h}$ inhibited the growth of $F$. solani with $\mathrm{IC}_{50}$ of $4.34-17.61 \mu \mathrm{g} / \mathrm{mL}$, which were stronger than that of the positive control, hymexazol ( $\mathrm{IC}_{50}$ of $38.92 \mu \mathrm{g} / \mathrm{mL}$ ). $5 \mathbf{h}$ was the most potent inhibitor $\left(\mathrm{IC}_{50}\right.$ of $4.34 \mu \mathrm{g} / \mathrm{mL}$ ) against $F$. Solani, which was about nine times more potent than hymexazol. Most of the test compounds displayed significant antifungal effects against $B$. cinerea $\left(\mathrm{IC}_{50}\right.$ of $19.92-77.41 \mu \mathrm{g} / \mathrm{mL}$ ), among them, $5 \mathbf{a}$ was the best one ( $\mathrm{IC}_{50}$ of $19.92 \mu \mathrm{g} / \mathrm{mL}$ ). The structure-activity relationships (SARs) were compared and analyzed. The result indicates that the electron-drawing ability and position of the substituents have a significant impact on biological activities. Furthermore, docking studies were carried out on the lipid transfer protein sec14p from S. cerevisiae, and preliminarily verified the antifungal activities. Taken together, these results provide 2-(phenoxymethyl)benzo[d]oxazole as an encouraging framework that could lead to the development of potent novel antifungal agents.
\end{abstract}

Keywords: benzoxazole derivatives; benzothiazole derivatives; fungicidal activity; plant pathogens; structure-activity relationships; molecular docking

\section{Introduction}

Plant diseases lead to serious losses to agriculture worldwide and pose an emerging threat to the global food security [1]. Especially, phytopathogenic fungi, which are extremely difficult to manage in agricultural production, have caused the most serious problems, accounting for $70-80 \%$ of plant diseases. Several important fungal plant pathogens, such as the genera Colletotrichum, Botrytis, Alternaria, and Fusarium have attracted great attention due to their typical infected disease symptoms (e.g., anthracnose caused by Colletotrichum species characterized by sunken necrotic lesions usually surrounded by a red margin) [2]. Chemical treatments have shown promising prospect in the control of the disease [3]. However, the chemicals have also led to fungicide resistance and environmental pollution, which may pose a serious risk to animal and human health [4]. Therefore, there is an increasing need for more safe and environment friendly antifungal agents to effectively control these plant diseases. 
The benzoxazole and benzothiazole scaffolds are found in various synthetic drugs displaying a broad-spectrum biological activities including antiparasitic, antibacterial, antiviral, cytotoxic, and herbicidal properties [5-7]. Thus they usually act as the important guide frame and parent skeleton, playing very important roles in medicinal chemistry and agrochemicals. For example, they can emerge as medicament because of their anti-inflammatory, antimalarial, and antitumor properties [8-10]. What is more, they often have such advantage as good selectivity, high activity and are eco-friendly compared with pesticides. Chemical structures of some drugs bearing benzoxazole and benzothiazole scaffolds are showed in Figure 1.

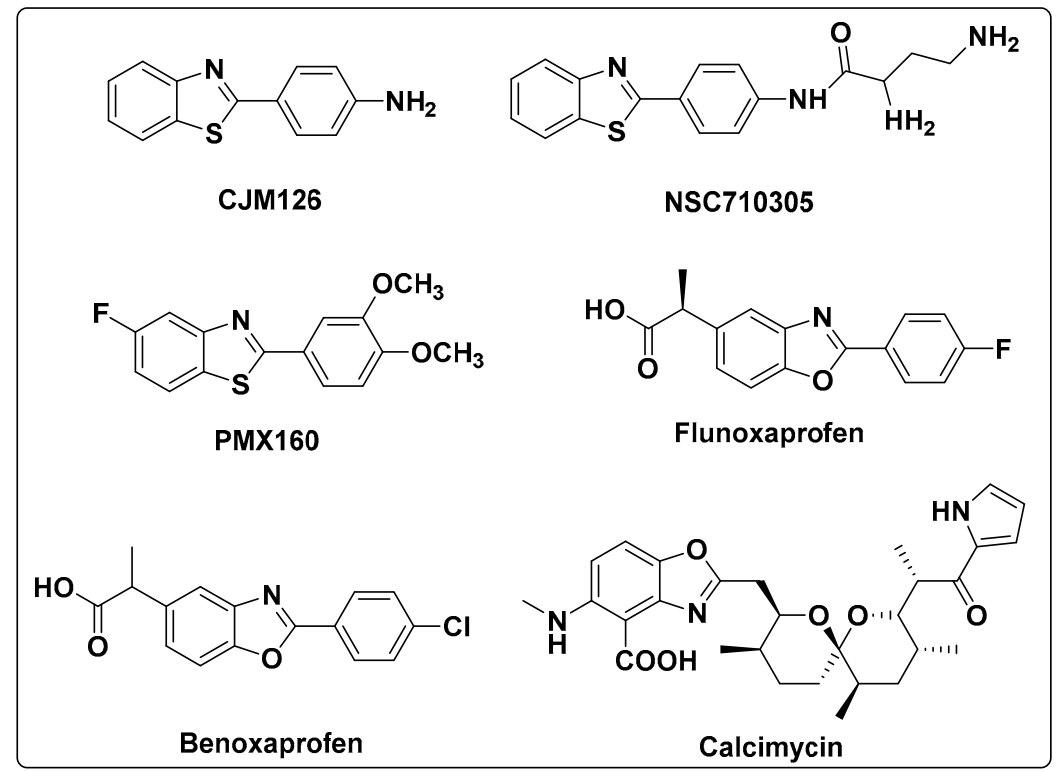

Figure 1. Chemical structures of some drugs bearing benzoxazole and benzothiazole scaffolds.

However, to the best of our knowledge, few reports [11,12] on fungicidal activity of benzoxazole and benzothiazole derivatives against plant pathogenic fungi have been published. The chemical structures of these antifungal compounds were showed in Figure 2. Thus, it is of great significance to design and synthesize antifungal compounds bearing benzoxazole and benzothiazole scaffolds.

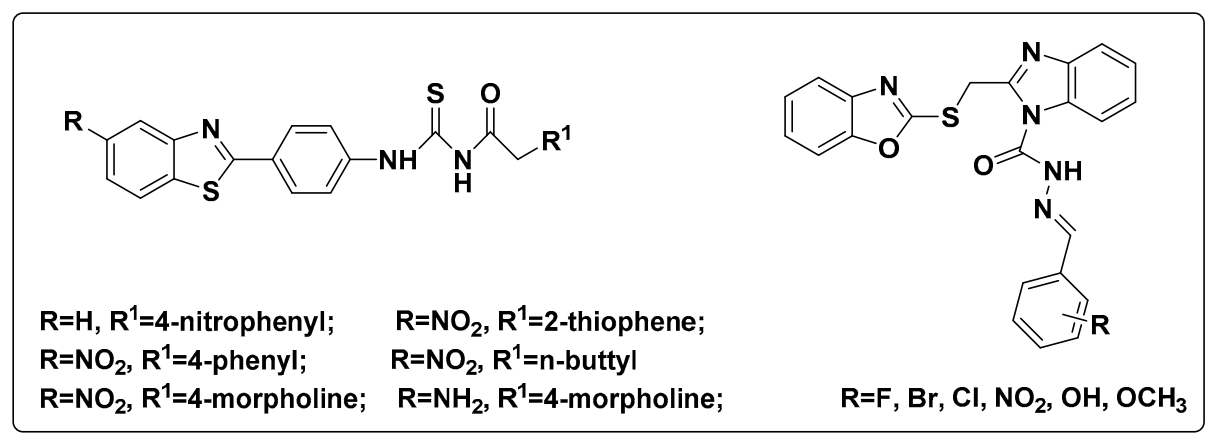

Figure 2. Chemical structures of the antifungal compounds bearing benzoxazole and benzothiazole scaffolds.

In our previous studies, benzimidazole derivatives and alkyl or benzyl acetophenone ether derivatives were synthesized, and some compounds showed promising fungicidal activities to plant pathogens $[13,14]$. In continuation of our investigation on antifungal compounds, two series of benzoxazole and benzothiazole derivatives were designed and synthesized from intermediates 2-chloromethyl-benzoxazole and 2-chloromethyl-benzothiazole through etherification 
reaction (Scheme 1), their structures were characterized by ${ }^{1} \mathrm{H}$ and ${ }^{13} \mathrm{C}-\mathrm{NMR}$ spectroscopy and mass spectroscopy (MS). Their fungicidal activities against eight agricultural phytopathogenic fungi were evaluated by the mycelium growth rate method, and the structure-activity relationships of these derivatives were also discussed.

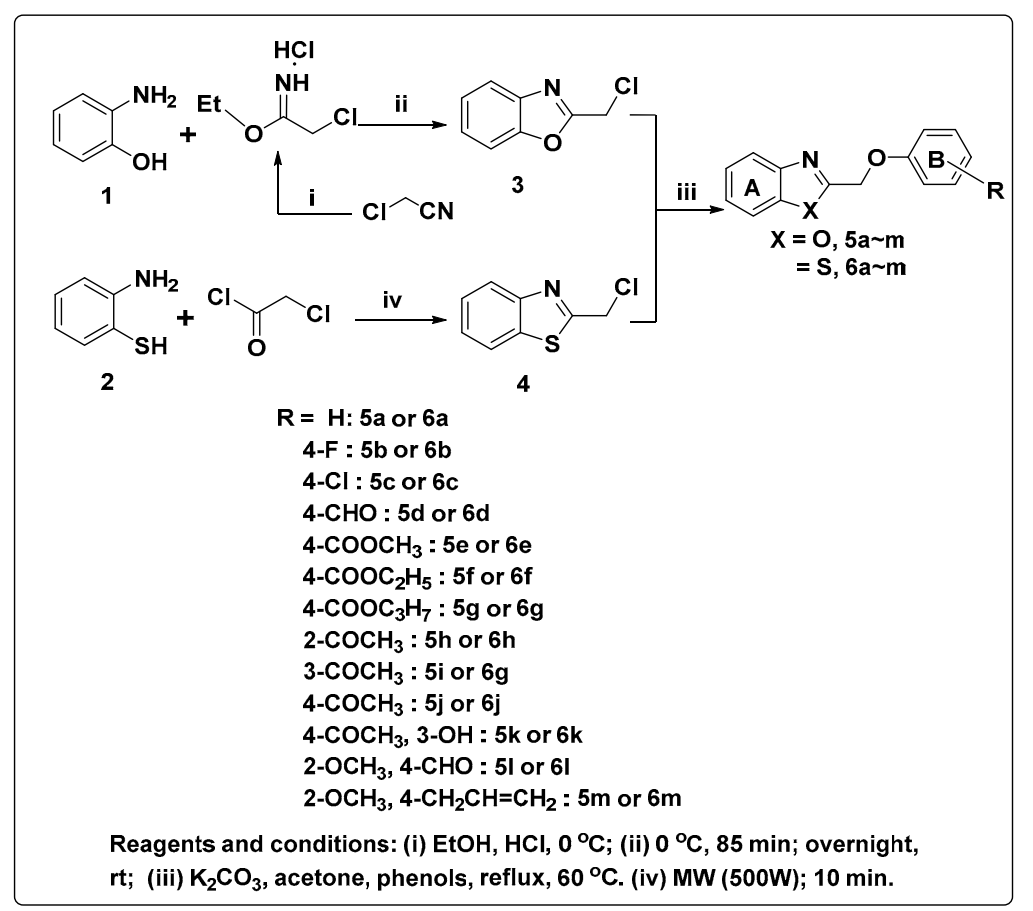

Scheme 1. Synthetic routes for 2-(Aryloxymethyl)-benzoxazole and -benzothiazole derivatives.

\section{Results and Discussion}

\subsection{Chemistry}

The synthetic pathways for the preparation of the target products $5 \mathbf{a}-\mathbf{m}$ and $\mathbf{6 a}-\mathbf{m}$ are shown in Scheme 1. In general, intermediate 2-chloromethyl-benzoxazole 3 can be commonly obtained by condensation of 2-aminophenol with chloroacetyl chloride [15,16] or chloroacetic acid [17]. We tried to adapt the methods reported, but the yield was unsatisfactory. In addition, both methods used polyphosphoric acid (PPA) as a reactant, which not only caused difficulty in aftertreatment but was also unfriendly to the environment $[18,19]$. In order to overcome these disadvantages, we reacted 2-aminophenol with ethyl chloroacetimidate hydrochloride in methylene chloride at $0{ }^{\circ} \mathrm{C}$ to provide the compound 3 with $86.5 \%$ yield according to the method described by Sheng [20].

Similarly, 2-chloromethyl-benzothiazole 4 can also be obtained from the condensation of 2-aminothiophenols with chloroacetyl chloride [21-23], chloroacetic acid [24-26], or chloroacetonitrile [9]. Firstly, we tried to prepare 4 according to these literatures, but the yield was not ideal. Then we employed a microwave-assisted procedure developed by Gellis [27], treating 2-aminobenzenethiol 2 with 2-chloroacetyl chloride in acetic acid under microwave irradiation for $10 \mathrm{~min}$ to provide the required intermediate 4, to our delight, the yield was up to $87 \%$. Compared with the traditional method, the microwave-assisted procedure was environmentally friendly and efficient, with a less time and higher yield. Furthermore, we also tried to prepare 3 by exploiting the microwave-assisted method, but it did not work. At last, Williamson reaction of $\mathbf{3}$ or $\mathbf{4}$ with different substituted phenols in dry acetone in the presence of anhydrous $\mathrm{K}_{2} \mathrm{CO}_{3}$ at reflux gave the desired compounds $5 \mathbf{a}-\mathbf{m}$ or $\mathbf{6 a}-\mathbf{m}$. 
The structures of the synthetic compounds and key intermediates were confirmed by ${ }^{1} \mathrm{H}-\mathrm{NMR}$, ${ }^{13} \mathrm{C}-\mathrm{NMR}$ and MS, as well as HRMS (High Resolution Mass Spectrum). Out of the 26 synthesized derivatives, 10 compounds (5d, 5f-i, 5k, 5m, 6g, 6k, and $6 \mathrm{~m})$ were novel.

\subsection{Antifungal Activity and Structure-Activity Relationships}

All the 2-(aryloxymethyl) benzoxazole and benzothiazole derivatives $(5 \mathbf{a}-\mathbf{m}, \mathbf{6 a}-\mathbf{m})$ obtained were screened for their preliminary antifungal activity in vitro. Their activities were evaluated on eight different phytopathogenic fungi: Fusarium oxysporum $f$. sp. niveum, Fusarium. graminearum, Fusarium. solani, Alternaria solani, Colletotrichum gloeosporioides, Valsa mali, Magnaporthe oryzae, and Botrytis cinerea (Table 1).

Table 1. Preliminary Antifungal Activities of Compounds at $100 \mu \mathrm{g} / \mathrm{mL}^{\mathrm{a}}$.

\begin{tabular}{|c|c|c|c|c|c|c|c|c|}
\hline \multirow{2}{*}{ Cpd. } & \multicolumn{8}{|c|}{ Average Values of Inhibition Rate (\%) to Eight Pathogens } \\
\hline & F. $n$. & F. $g$. & F. s. & A. s. & C. $g$. & V. $m$. & M. o. & B. $c$. \\
\hline $5 \mathbf{a}$ & 85 & 87 & 100 & 92 & 100 & 100 & 95 & 100 \\
\hline $5 b$ & 51 & 30 & 85 & 69 & 70 & 43 & 72 & 80 \\
\hline $5 c$ & 44 & 30 & 41 & 57 & 37 & 39 & 44 & 68 \\
\hline $5 d$ & 38 & 45 & 43 & 34 & 57 & 44 & 38 & 78 \\
\hline $5 e$ & 44 & 38 & 41 & 37 & 33 & 46 & 25 & 33 \\
\hline $5 f$ & 28 & 34 & 57 & 43 & 49 & 49 & 44 & 62 \\
\hline $5 \mathrm{~g}$ & 26 & 30 & 47 & 57 & 45 & 36 & 53 & 61 \\
\hline $5 \mathrm{~h}$ & 62 & 30 & 89 & 69 & 56 & 80 & 55 & 72 \\
\hline $5 \mathbf{i}$ & 59 & 30 & 87 & 63 & 61 & 90 & 81 & 79 \\
\hline $5 \mathbf{j}$ & 39 & 49 & 78 & 43 & 57 & 53 & 50 & 33 \\
\hline $5 \mathbf{k}$ & 18 & 24 & 23 & 9 & 25 & 20 & 19 & 44 \\
\hline 51 & 33 & 40 & 23 & 29 & 45 & 29 & 34 & 39 \\
\hline $5 \mathrm{~m}$ & 35 & 27 & 58 & 56 & 47 & 72 & 50 & 58 \\
\hline $6 a$ & 35 & 56 & 49 & 36 & 47 & 36 & 39 & 93 \\
\hline $6 b$ & 28 & 30 & 34 & 26 & 29 & 36 & 25 & 36 \\
\hline $6 c$ & 21 & 32 & 28 & 34 & 57 & 19 & 72 & 67 \\
\hline $6 d$ & 16 & 32 & 51 & 16 & 35 & 43 & 34 & 45 \\
\hline $6 e$ & 33 & 18 & 28 & 5 & 22 & 38 & 16 & 22 \\
\hline $6 f$ & 8 & 30 & 23 & 9 & 18 & 12 & 6 & 33 \\
\hline $6 \mathrm{~g}$ & 3 & 20 & 32 & 3 & 14 & 53 & 62 & 11 \\
\hline $6 \mathrm{~h}$ & 39 & 71 & 69 & 28 & 81 & 46 & 44 & 52 \\
\hline $6 i$ & 20 & 24 & 19 & 32 & 32 & 16 & 25 & 52 \\
\hline $6 j$ & 18 & 28 & 23 & 9 & 18 & 9 & 20 & 28 \\
\hline $6 \mathrm{k}$ & 1 & 14 & 34 & 16 & 26 & 22 & 24 & 59 \\
\hline 61 & 31 & 28 & 34 & 46 & 25 & 12 & 25 & 81 \\
\hline $6 \mathrm{~m}$ & 16 & 56 & 50 & 20 & 32 & 36 & 48 & 59 \\
\hline Hy & 69 & 71 & 88 & 63 & 20 & 16 & 100 & 100 \\
\hline
\end{tabular}

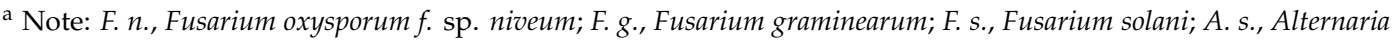
solani; C. g., Colletotrichum gloeosporioides; V. m., Valsa mali; M. o., Magnaporthe oryzae; B. c., Botrytis cinerea; and Hy, hymexazol.

The initial results showed in Table 1 indicated that some of these synthetic compounds presented significant antifungal effects. These results encouraged us to continue our investigations into further evaluation of their antifungal effects according to the inhibition rates over $60 \%$ that were determined for $\mathrm{IC}_{50}$ values (Table 2). 
Table 2. $\mathrm{IC}_{50}$ values of Some Compounds on Eight Phytopathogenic Fungi ${ }^{\mathrm{a}}$.

\begin{tabular}{|c|c|c|c|c|c|c|c|c|}
\hline \multirow{2}{*}{ Cpd. } & \multicolumn{8}{|c|}{$\mathrm{IC}_{50} \pm \mathrm{SD} /(\mu \mathrm{g} / \mathrm{mL})$} \\
\hline & F. $n$. & F. $g$. & F.s. & A. s. & C. $g$. & V. $m$. & M. o. & B. $c$. \\
\hline $5 a$ & $45.00 \pm 2.71$ & $20.59 \pm 2.34$ & $12.27 \pm 0.88$ & $23.23 \pm 1.58$ & $25.94 \pm 2.53$ & $23.52 \pm 1.63$ & $65.25 \pm 2.98$ & $19.92 \pm 3.34$ \\
\hline $5 b$ & $>100$ & $>100$ & $15.98 \pm 1.15$ & $32.10 \pm 7.11$ & $32.78 \pm 2.11$ & $>100$ & $30.61 \pm 0.73$ & $23.78 \pm 1.55$ \\
\hline $5 c$ & $>100$ & $>100$ & $>100$ & $>100$ & $>100$ & $>100$ & $>100$ & $50.04 \pm 6.03$ \\
\hline $5 f$ & $>100$ & $>100$ & $>100$ & $>100$ & $>100$ & $>100$ & $>100$ & $73.04 \pm 3.54$ \\
\hline $5 g$ & $>100$ & $>100$ & $>100$ & $>100$ & $>100$ & $>100$ & $>100$ & $77.41 \pm 3.16$ \\
\hline $5 \mathrm{~h}$ & $94.48 \pm 2.28$ & $>100$ & $4.34 \pm 0.13$ & $33.32 \pm 2.82$ & $>100$ & $31.34 \pm 2.64$ & $>100$ & $35.52 \pm 2.95$ \\
\hline $5 \mathbf{i}$ & $>100$ & $>100$ & $17.61 \pm 0.93$ & $73.09 \pm 4.10$ & $83.35 \pm 1.04$ & $37.98 \pm 2.75$ & $73.62 \pm 5.12$ & $42.01 \pm 2.76$ \\
\hline $5 \mathbf{j}$ & $>100$ & $>100$ & $16.53 \pm 1.89$ & $>100$ & $>100$ & $>100$ & $>100$ & $>100$ \\
\hline $5 \mathrm{~m}$ & $>100$ & $>100$ & $>100$ & $>100$ & $>100$ & $59.65 \pm 5.0$ & $>100$ & $>100$ \\
\hline $6 a$ & $>100$ & $>100$ & $>100$ & $>100$ & $>100$ & $>100$ & $>100$ & $62.62 \pm 2.17$ \\
\hline $6 c$ & $>100$ & $>100$ & $>100$ & $>100$ & $>100$ & $>100$ & $>100$ & $61.20 \pm 4.91$ \\
\hline $6 h$ & $>100$ & $23.39 \pm 1.29$ & $15.55 \pm 1.35$ & $>100$ & $29.61 \pm 1.39$ & $>100$ & $>100$ & $>100$ \\
\hline 61 & $>100$ & $>100$ & $>100$ & $>100$ & $>100$ & $>100$ & $>100$ & $50.42 \pm 5.75$ \\
\hline Hy & $8.47 \pm 1.72$ & $59.93 \pm 2.19$ & $38.92 \pm 3.17$ & $54.16 \pm 1.46$ & $>100$ & $>150$ & $35.40 \pm 2.38$ & $4.72 \pm 0.52$ \\
\hline
\end{tabular}

a Note: The results were expressed as the mean \pm SD of triplicate experiments. 
Compounds (5a, 5b, 5c, 5f, 5g, 5h, 5i, 5j, 5m, 6a, $6 c, 6 \mathrm{~h}$, and 61 ) displayed varying degrees of antifungal activities against several plant pathogenic fungi tested, while the other compounds showed lower activities, compared with the positive control hymexazol.

\subsubsection{Antifungal Activity of the Benzoxazole Derivatives}

As shown in Table 2, of the test benzoxazole derivatives, compound 5 a with a non-substituted phenyl ring $B$ exhibited a broad spectrum of biological activity on all of the eight species of plant pathogens ( $\mathrm{IC}_{50}$ of $12.27-65.25 \mu \mathrm{g} / \mathrm{mL}$ ). $\mathbf{5 b}$ with a fluorine group had good antifungal activities against F. Solani, A. solani, C. gloeosporioides, M. oryzae, and B. cinerea, showing $\mathrm{IC}_{50}$ values in the range of 15.98 to $32.78 \mu \mathrm{g} / \mathrm{mL}$. However, $5 \mathrm{c}$ only effected to B. Cinerea ( $\mathrm{IC}_{50}$ of $50.04 \mu \mathrm{g} / \mathrm{mL}$ ). Notably, the order of antifungal activity of $\mathbf{5 a}, \mathbf{5 b}$, and $\mathbf{5 c}$ against most of the eight plant pathogens was $\mathbf{5 a}>\mathbf{5 b}>\mathbf{5 c}$. The results suggested that the introduction of a chlorine or a fluorine atom into the phenyl ring of $5 \mathbf{a}$ decreased antifungal activity and the introduction of $\mathrm{F}$ into $\mathbf{5 a}$ produced higher broad-spectrum antifungal properties than that of $\mathrm{Cl}$. In general, introduction of halogens such as chlorine or fluorine atom into pesticides can enhance activity. But our results were diametric. We supposed one reason was that introducing the electron-withdrawing group on the benzene ring will change the extension direction of the benzene ring, thus weakening the van der Waals interactions with residues Ser201, Gln202, Try205, Pro205, Arg208, and Met209.

Inhibitory activity of $\mathbf{5} \mathbf{f}$ and $\mathbf{5 g}$, possessing an aliphatic formate group (e.g., $-\mathrm{CO}_{2} \mathrm{C}_{2} \mathrm{H}_{5}$ ), against B. cinerea was almost similar, with $\mathrm{IC}_{50}$ values of 73.04 and $77.41 \mu \mathrm{g} / \mathrm{mL}$, respectively, but were inactive against the other fungi tested, indicating the aliphatic formate on the $p$-position of B-ring of benzoxazole derivatives is detrimental to activity.

In addition, the order of antifungal activity of $5 \mathbf{h}, \mathbf{5 i}$, and $5 \mathbf{j}$, which all carried a COMe group, against $F$. solani was $5 \mathbf{h}>\mathbf{5 j}>\mathbf{5 i}$, with their $\mathrm{IC}_{50}$ data of $4.34,16.53$ and $17.61 \mu \mathrm{g} / \mathrm{mL}$, respectively, which were all better than the control ( $\mathrm{IC}_{50}$ of $38.92 \mu \mathrm{g} / \mathrm{mL}$ ), indicating $5 \mathrm{~h}$ to be the most active compound. In comparison to the other pathogenic organisms tested, $5 \mathbf{h}$ and $5 \mathbf{i}$ produced more broad-spectrum antifungal properties than that of $\mathbf{5 j}$. These observations suggested that the acetyl group on $o$-position and $m$-position of acetophenones of benzoxazoles is better than $p$-position in antifungal activity.

\subsubsection{Antifungal Activity of the Benzothiazole Derivatives}

Most of the test benzothiazole derivatives exerted weak antifungal activity (Tables 1 and 2). However, among the test compounds $\mathbf{6 a}, \mathbf{6 c}, \mathbf{6 h}$, and $\mathbf{6 1}$, compound $\mathbf{6 h}$, containing an electron-withdrawing acetyl group on the 2-position of the phenyl ring, significantly inhibited the mycelial growth of of F. graminearum, F. Solani and C. gloeosporioides, with IC $_{50}$ values of 23.39, 15.55 and $29.61 \mu \mathrm{g} / \mathrm{mL}$, respectively, but were essentially inactive against the other five fungi (Table 2). Additionally, $\mathbf{6 a}, \mathbf{6 c}$, and $\mathbf{6 1}$ elicited selective and moderate inhibitory effects against $B$. cinerea, with $\mathrm{IC}_{50}$ values of $62.62,61.20$, and $50.42 \mu \mathrm{g} / \mathrm{mL}$, respectively, while being almost inactive to the other organisms tested.

On the other hand, most of the test compounds exhibited moderate to strong inhibitory effects on F. solani $\left(\mathrm{IC}_{50}\right.$ of $4.34-17.61 \mu \mathrm{g} / \mathrm{mL}$ ) and B. cinerea $\left(\mathrm{IC}_{50}\right.$ of $\left.19.92-77.41 \mu \mathrm{g} / \mathrm{mL}\right)$, implying that they are more sensitive to F. solani and B. cinerea than the other six organisms. Interestingly, between the two species of the genus Fusarium tested, F. solani is more sensitive.

Comparing the antifungal activity of benzoxazole derivatives with benzothiazole derivatives, antifungal effects of most of benzoxazole derivatives were better than those of benzothiazoles, showing that the benzoxazole derivatives may have a more promising future as fungicides. For example, Compound $\mathbf{5 a}$ was three-fold more active than the corresponding $\mathbf{6 a}$ in antifungal potency against B. cinerea ( $\mathrm{IC}_{50}$ of 19.92 and $62.62 \mu \mathrm{g} / \mathrm{mL}$ respectively). The structure activity relationship of the synthesized compounds is shown in Figure 3. 


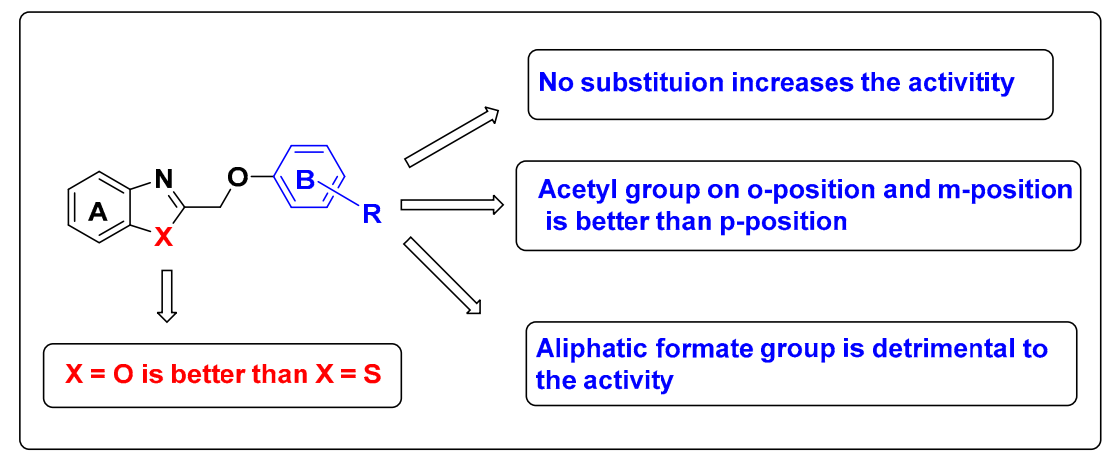

Figure 3. Structure activity relationship of the synthesized compounds.

\subsection{Molecular Docking Studies}

Molecular docking is a fast and efficient computational method to predict the bioactive compounds to a specific protein or reversely predict the target proteins for one bioactive compound [28]. The significant experimental antifungal activities of compounds $\mathbf{5 a}, \mathbf{5} \mathbf{b}, \mathbf{5} \mathbf{h}, \mathbf{5 i}$, $5 \mathbf{j}$, and $\mathbf{6 h}$ provide a hint to performing molecular docking studies to identify the potential target. On the one hand, reverse docking was applied to predict the probable targets of the title compounds from antifungal drug proteins, such as sterol 14-alpha demethylase, squalene epoxidase, chitin synthase, fattyacid synthase, $N$-myristoyltransferase, and tubulin, etc. On the other hand, after reviewing the different chemical classes that docked into the Sec14p active site, such as nitrophenyl(4-(2-methoxyphenyl)piperazin-1-yl)methanones (NPPMs), picolinamide, and benzamide chemotypes, we examined our compounds on the active site because some structural similarities exist. The results showed that lipid transfer protein Sec14p might be a potential target for our compounds. Sec14-like phosphatidylinositol transfer proteins (PITPs) integrate diverse territories of intracellular lipid metabolism with stimulated phosphatidylinositol-4-phosphate production and are discriminating portals for interrogating phosphoinositide signaling [29]. Sec14p, the major PITP, executes essential functions in several pathogenic fungi and it is required for the efficient secretion of pathogenicity factors. It is an attractive antifungal target as it has been shown to be druggable [30,31].

The picolinamide (PIA) and the benzamide (BEA), reported by professor Hoepfner, are two antifungal compounds with $\mathrm{IC}_{50}$ values of 28.5 and $6.6 \mu \mathrm{M}$ against $S$. cerevisiae, respectively. To test this hypothesis, PIA and BEA, as the reference inhibitors, were also docked into the lipid binding pocket of Sec14p. In the resulting docking model, the binding pose of PIA was almost identical to the crystallographic one (PDB 6F0E) (Figure 4A). The binding energy of PIA and BEA were -6.96 and $-7.54 \mathrm{kcal} / \mathrm{mol}$, and the inhibit constants were predicted to be 7.97 and $2.99 \mu \mathrm{M}$, respectively, which were similar to the experimental in vitro data (Table 3). All these results showed the docking protocols were appropriate and feasible. As shown in Figure 4, the six-test compound shared very similar binding modes with comparable binding affinities (Table 3). The benzoxazole and benzothiazole ring pointed toward the core of the cavity and engaged in a $\pi-\pi$ stacking interaction with Tyr151. The phenoxyl ether moieties were oriented toward solvent and made van der Waals interactions with residues Ser201, Gln202, Try205, Pro205, Arg208, and Met209. A hydrogen-bond (H-bond) interaction between the carboxyl of Ser173 and the heteroatom in the benzoxazole ring of the compound $\mathbf{5 b}$ (or $5 \mathbf{i} / 5 \mathbf{j}$ ) could be observed. The binding models of $5 \mathbf{h}, 5 \mathbf{i}$, and $5 \mathbf{j}$ outlines that the acetyl group on the $p$-position of acetophenones of benzoxazoles destabilized the $\pi-\pi$ stacking interaction between the benzoxazole ring with Tyr151 and would be deleterious for ligand binding. Additionally, the number of binding energy (or inhibit constant) for benzoxazole and benzothiazole derivatives with Sec14p, and that for PIA and BEA, it was in the same order of magnitude, which may be one reason for these compounds with different molecular skeleton having similar fungicidal activity. 
A

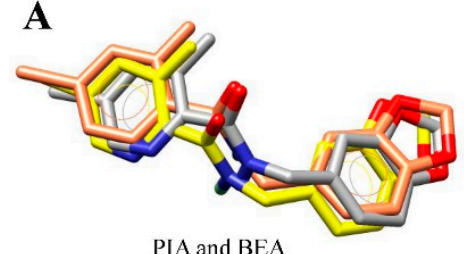

PIA and BEA
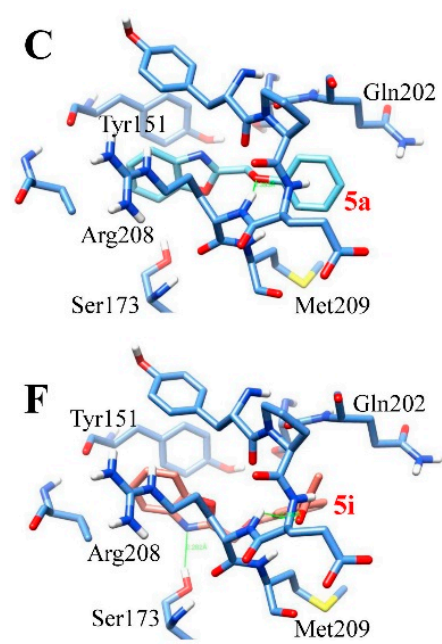
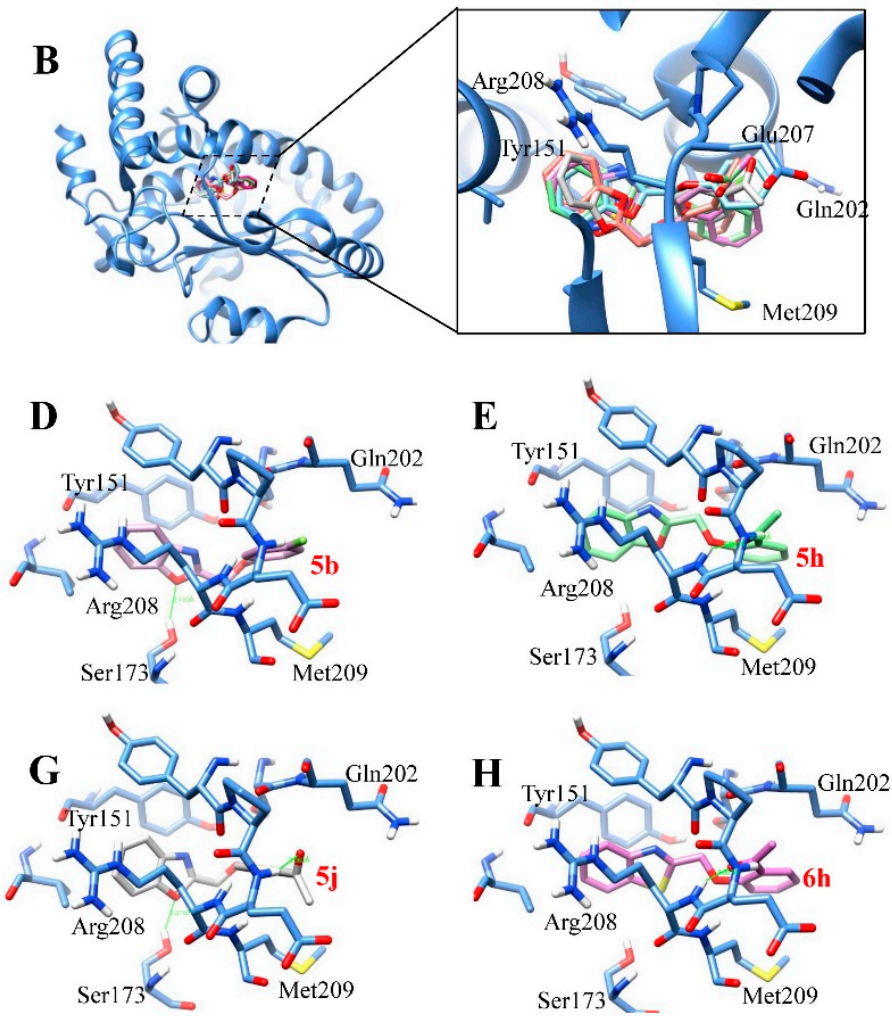

Figure 4. The binding models of the test compounds into the lipid binding pocket of Sec14p from S. cerevisiae. (A) Superposition of PIA (yellow) and BEA (orange) in docking resultant models with PIA in the X-ray crystallographic structure (PDB 6F0E; gray). (B) Overlay of the six test benzoxazole and benzothiazole derivatives. $(\mathrm{C}-\mathrm{H})$ The binding modes of the compounds (in stick model with carbon) into the active site of Sec14p: (C) 5a (aquamarine); (D) $5 \mathbf{b}$ (orchid); (E) $5 \mathrm{~h}$ (light green); (F) $5 \mathbf{i}$ (coral); (G) $5 \mathbf{j}$ (light gray); and (H) $6 \mathrm{~h}$ (hot pink).

Table 3. The docking results of the tested compounds.

\begin{tabular}{ccc}
\hline Cpd. & Binding Energy (kcal/mol) & Inhibit Constant $(\mu \mathbf{M})$ \\
\hline $\mathbf{5 a}$ & -6.89 & 8.92 \\
$\mathbf{5 b}$ & -6.86 & 9.39 \\
$\mathbf{5 h}$ & -7.38 & 3.9 \\
$\mathbf{5 i}$ & -7.66 & 2.44 \\
$\mathbf{5 j}$ & -7.85 & 1.78 \\
$\mathbf{6 h}$ & -7.76 & 2.06 \\
PIA $^{\mathrm{a}}$ & -6.96 & $7.97(9.4)^{\mathrm{c}}$ \\
BEA $^{\mathrm{b}}$ & -7.54 & $2.99(1.7)^{\mathrm{c}}$ \\
\hline
\end{tabular}

a The inhibitor co-crystals with Sec14p from S. cerevisiae in the crystal structure of the protein complex (PDB code: $6 \mathrm{FOE}) .{ }^{\mathrm{b}}$ The benzamide compound 2 in the reference. ${ }^{\mathrm{c}}$ The value in parenthesis are $\mathrm{IC}_{50}$ for the active compound against Sec14p from S. cerevisiae.

\section{Materials and Methods}

\subsection{Chemistry}

All of the commercial solvents and reagents were of reagent grade. The melting points of test compounds were measured on an X-4 apparatus (Beijing Tech Instrument Co., Beijing, China) and uncorrected. ${ }^{1} \mathrm{H}-\mathrm{NMR}$ and ${ }^{13} \mathrm{C}-\mathrm{NMR}$ spectra were recorded on a Bruker Avance III $500 \mathrm{MHz}$ spectrometer (Bruker Bios pin, Rheinstetten, Germany) with in $\mathrm{CDCl}_{3}$ with tetramethylsilane (TMS) as internal reference. High-resolution electrospray ionization mass spectrometry (HRESIMS) data were recorded on LCMS-IT-TOF (Shimadzu, Kyoto, Japan). Thin-layer chromatography (TLC) 
was performed on silica gel $60 \mathrm{~F}_{254}$ (Qingdao Marine Chemical Ltd., Qingdao, China). Column chromatography (CC) was performed over silica gel (200-300 mesh, Qingdao Marine Chemical Ltd., Qingdao, China).

\subsubsection{General Experimental Procedures}

Synthesis of ethyl chloroacetimidate hydrochloride. A solution of chloroacetonitrile (10.0 $\mathrm{g}$, $133 \mathrm{mmol})$, ethanol $(6.8 \mathrm{~g}, 148 \mathrm{mmol})$, and dry ether $(76 \mathrm{~mL})$ was stirred and cooled at $0{ }^{\circ} \mathrm{C}$ while a stream of dry $\mathrm{HCl}$ gas was bubbled through. After $0.5 \mathrm{~h}$, the white crystalline salt had precipitated. Excess dry ether was added to the mixture, which was then filtered, washed with dry ether, and stored over $\mathrm{P}_{2} \mathrm{O}_{5}$ in vacuo, leading to ethyl chloroacetimidate hydrochloride as a white solid (16 g, yield 77.6\%) [14]. m.p., 89-91 ${ }^{\circ} \mathrm{C}$.

Synthesis of 2-Chloromethyl-benzoxazole (3) [20]. To a solution of 2-aminophenol (3.76 g, $34.5 \mathrm{mmol})$ in methylene chloride at $0{ }^{\circ} \mathrm{C}$ was added ethyl chloroacetimidate hydrochloride $(7.98 \mathrm{~g}$, $50.5 \mathrm{mmol}$ ). After $85 \mathrm{~min}$, the reaction mixture was allowed to warm to room temperature, while being stirred overnight. The mixture was filtered over diatomite and concentrated to oil under reduced pressure. The resulting residue was purified by column chromatography on silica gel (petroleum ether/acetone, 10:1 v:v) to obtain compound 3 as a white solid $(5.00 \mathrm{~g}, 86.5 \%)$. m.p., $152-154{ }^{\circ} \mathrm{C}$; MS (+ESI) $m / z 168.05[\mathrm{M}+\mathrm{H}]^{+}$.

Synthesis of 2-Chloromethyl-benzothiazole (4) [27]. To a solution of 2-aminobenzenethiol $(1 \mathrm{~g}$, $7.93 \mathrm{mmol})$ in acetic acid $(15 \mathrm{~mL})$, and 2-chloroacetyl chloride $(1.35 \mathrm{~g}, 1.19 \mathrm{mmol})$ was added dropwise. The reaction mixture was irradiated in a microwave oven (Ethos start) for $10 \mathrm{~min}$ at a power of $500 \mathrm{~W}$. After cooling, the mixture was poured onto crushed ice $(100 \mathrm{~mL})$ and basified with $5 \mathrm{~mol} / \mathrm{L} \mathrm{NaOH}$. The solution was extracted with chloroform $(3 \times 50 \mathrm{~mL})$. The combined organic layers were dried over $\mathrm{MgSO}_{4}$ and concentrated under vacuum. Purification of the residue by column chromatography on silica gel (petroleum ether/acetone, 10:1 v:v) gave compound 4 as a yellow solid (1.90 g, 86.8\%) [27]. m.p., 89-90 ${ }^{\circ} \mathrm{C}$; MS (+ESI) $m / z 184.02[\mathrm{M}+\mathrm{H}]^{+}$.

3.1.2. General Procedure for the Synthesis of the Benzoxazole and Benzothiazole Derivatives $(5 a-m, 6 a-m)$

To a solution of various substituted phenols $(1 \mathrm{mmol})$ in dry acetone $(30 \mathrm{~mL}) \mathrm{K}_{2} \mathrm{CO}_{3}(1 \mathrm{mmol})$ and compound 3 or $4(1 \mathrm{mmol})$ were added. After being stirred for $4 \mathrm{~h}$ at reflux temperature, the reaction mixture was cooled, filtered, and concentrated under vacuum. Then the residue was diluted with $30 \mathrm{~mL}$ ethyl acetate and sequentially washed with $30 \mathrm{~mL} 1 \mathrm{M} \mathrm{HCl}$, aq. $\mathrm{NaHCO}_{3}$ solution and brine in order. The organic layer was dried over $\mathrm{MgSO}_{4}$ and concentrated in vacuo. Purification of the residue by chromatography on silica gel furnished target compounds. ${ }^{1} \mathrm{H}-\mathrm{NMR},{ }^{13} \mathrm{C}-\mathrm{NMR}$ and mass spectroscopy (MS) of compounds $\mathbf{5 a}-\mathbf{m}$ and $\mathbf{6} \mathbf{a}-\mathbf{m}$ are shown in Supplementary Materials.

2-(phenoxymethyl)benzo[d] ]oxazole (5a): Yellow solid; yield, 75.56\%; m.p., 154-156 ${ }^{\circ} \mathrm{C} ;{ }^{1} \mathrm{H}-\mathrm{NMR}(500 \mathrm{MHz}$, $\left.\mathrm{CDCl}_{3}\right) \delta 7.76(\mathrm{~m}, 1 \mathrm{H}, \mathrm{ArH}), 7.56(\mathrm{~d}, J=6.9 \mathrm{~Hz}, 1 \mathrm{H}, \mathrm{ArH}), 7.37(\mathrm{~m}, 2 \mathrm{H}, \mathrm{ArH} \times 2), 7.32(\mathrm{t}, J=7.7 \mathrm{~Hz}, 2 \mathrm{H}$, $\mathrm{ArH} \times 2), 7.07(\mathrm{~d}, J=8.4 \mathrm{~Hz}, 2 \mathrm{H}, \mathrm{ArH} \times 2), 7.02(\mathrm{t}, J=7.3 \mathrm{~Hz}, 1 \mathrm{H}, \mathrm{ArH}), 5.33\left(\mathrm{~s}, 2 \mathrm{H}, \mathrm{CH}_{2}\right)$; and ESI-MS $m / z: 225.94\left([\mathrm{M}+\mathrm{H}]^{+}\right), 247.92\left([\mathrm{M}+\mathrm{Na}]^{+}\right)$.

2-((4-fluorophenoxy)methyl)benzo[d]oxazole (5b): Yellow solid; yield, 83.13\%; m.p., $62-63{ }^{\circ} \mathrm{C} ;{ }^{1} \mathrm{H}-\mathrm{NMR}$ $(500 \mathrm{MHz}, \mathrm{CDCl} 3) \delta 7.76(\mathrm{dd}, J=5.9,2.5 \mathrm{~Hz}, 1 \mathrm{H}, \mathrm{ArH}), 7.55(\mathrm{~m}, 1 \mathrm{H}, \mathrm{ArH}), 7.36(\mathrm{dd}, J=5.7,2.3 \mathrm{~Hz}, 2 \mathrm{H}$, $\mathrm{ArH} \times 2), 7.13-6.92(\mathrm{~m}, 4 \mathrm{H}, \mathrm{ArH} \times 4), 5.28(\mathrm{~s}, 2 \mathrm{H},-\mathrm{CH} 2-\mathrm{O}-)$; and ESI-MS m/z: $244.07\left([\mathrm{M}+\mathrm{H}]^{+}\right)$.

2-((4-chlorophenoxy)methyl)benzo[d] ]oxazole (5c): Yellow solid; yield, 82.31\%; m.p., 85-86 ${ }^{\circ} \mathrm{C} ;{ }^{1} \mathrm{H}-\mathrm{NMR}$ (500 MHz, CDCl3) 8 $7.74(\mathrm{~m}, 1 \mathrm{H}, \mathrm{ArH}), 7.53(\mathrm{dd}, J=7.3,1.1 \mathrm{~Hz}, 1 \mathrm{H}, \mathrm{ArH}), 7.35(\mathrm{~m}, 2 \mathrm{H}, \mathrm{ArH} \times 2), 7.22$ $(\mathrm{d}, J=9.0 \mathrm{~Hz}, 2 \mathrm{H}, \mathrm{ArH} \times 2), 6.96(\mathrm{~d}, J=8.9 \mathrm{~Hz}, 2 \mathrm{H}, \mathrm{ArH} \times 2), 5.27(\mathrm{~s}, 2 \mathrm{H},-\mathrm{CH} 2-\mathrm{O}-)$; and ESI-MS $m / z$ : $259.84\left([\mathrm{M}+\mathrm{H}]^{+}\right), 281.85\left([\mathrm{M}+\mathrm{Na}]^{+}\right)$. 
4-(benzo[d]oxazol-2-ylmethoxy)benzaldehyde (5d): White solid; yield, 34\%; m.p., $138-140{ }^{\circ} \mathrm{C} ;{ }^{1} \mathrm{HNMR}$ $(500 \mathrm{MHz}, \mathrm{CDCl} 3) \delta 9.89(d, J=12.2 \mathrm{~Hz}, 1 \mathrm{H},-\mathrm{CHO}), 7.86(\mathrm{~d} d, J=9.4,2.5 \mathrm{~Hz}, 2 \mathrm{H}, \mathrm{ArH} \times 2), 7.77(\mathrm{~m}, 1 \mathrm{H}$, $\mathrm{ArH}), 7.56(\mathrm{~d}, J=7.3 \mathrm{~Hz}, 1 \mathrm{H}, \mathrm{ArH}), 7.38(\mathrm{~m}, 2 \mathrm{H}, \mathrm{ArH} \times 2), 7.18(\mathrm{~d}, J=8.7 \mathrm{~Hz}, 2 \mathrm{H}, \mathrm{ArH} \times 2), 5.41(\mathrm{~d}$, $J=7.2 \mathrm{~Hz}, 2 \mathrm{H}, \mathrm{CH} 2) ; 13 \mathrm{C}$ NMR $(125 \mathrm{MHz}, \mathrm{CDCl} 3) \delta 190.9$ (C=O), 162.8 (-N=C-O-), 160.7 (ArC), 151.2 (ArC), 140.7 (ArC), $132.3(\mathrm{ArC}), 131.2(\mathrm{ArC}), 126.2(\mathrm{ArC}), 125.1(\mathrm{ArC}), 120.7(\mathrm{ArC}), 115.4(\mathrm{ArC}), 111.2$ (ArC), 63.0 (-CH2O-); HR-MS (ESI): $m / z$ calcd. for C15H11NO3: 254.0812; found: $254.0785[\mathrm{M}+\mathrm{H}]^{+}$. methyl 4-(benzo[d] ]oxazol-2-ylmethoxy)benzoate (5e): White solid; yield, 67.14\%; m.p., 97-99 ${ }^{\circ} \mathrm{C} ;{ }^{1} \mathrm{H}-\mathrm{NMR}$ $(500 \mathrm{MHz}, \mathrm{CDCl} 3) \delta 8.01(\mathrm{dd}, J=11.5,4.5 \mathrm{~Hz}, 2 \mathrm{H}, \mathrm{ArH} \times 2), 7.77(\mathrm{~m}, 1 \mathrm{H}, \mathrm{ArH}), 7.56(\mathrm{~d}, J=7.2 \mathrm{~Hz}, 1 \mathrm{H}$, $\mathrm{ArH}), 7.37(\mathrm{~m}, 2 \mathrm{H}, \mathrm{ArH} \times 2), 7.08(\mathrm{dd}, J=11.5,4.5 \mathrm{~Hz}, 2 \mathrm{H}, \mathrm{ArH} \times 2), 5.37(\mathrm{~d}, J=9.1 \mathrm{~Hz}, 2 \mathrm{H}, \mathrm{CH} 2), 3.87$ $(\mathrm{d}, J=8.8 \mathrm{~Hz}, 3 \mathrm{H}, \mathrm{CH} 3)$; ESI-MS $m / z: 284.37([\mathrm{M}+\mathrm{H}]+), 306.81\left([\mathrm{M}+\mathrm{Na}]^{+}\right)$.

ethyl 4-(benzo[d] ]oxazol-2-ylmethoxy)benzoate (5f): Yellow solid; yield, 67.34\%; m.p., $70-72{ }^{\circ} \mathrm{C} ;{ }^{1} \mathrm{H}-\mathrm{NMR}$ $(500 \mathrm{MHz}, \mathrm{CDCl} 3) \delta 8.02(\mathrm{~d}, J=8.7 \mathrm{~Hz}, 2 \mathrm{H}, \mathrm{ArH} \times 2), 7.77(\mathrm{~m}, 1 \mathrm{H}, \mathrm{ArH}), 7.55(\mathrm{~m}, 1 \mathrm{H}, \mathrm{ArH}), 7.37$ $(\mathrm{dd}, J=7.4,3.6 \mathrm{~Hz}, 2 \mathrm{H}, \mathrm{ArH} \times 2), 7.08(\mathrm{~d}, J=8.7 \mathrm{~Hz}, 2 \mathrm{H}, \mathrm{ArH} \times 2), 5.38(\mathrm{~s}, 2 \mathrm{H},-\mathrm{CH} 2-\mathrm{O}-), 4.34(\mathrm{~d}$, $J=7.1 \mathrm{~Hz}, 2 \mathrm{H},-\mathrm{CH} 2-\mathrm{CH} 3), 1.37(\mathrm{t}, J=7.1 \mathrm{~Hz}, 3 \mathrm{H}, \mathrm{CH} 3) ;{ }^{13} \mathrm{C}-\mathrm{NMR}(125 \mathrm{MHz}, \mathrm{CDCl} 3) \delta 166.4(\mathrm{C}=\mathrm{O})$, 161.6 (-N=C-O-), $161.0(\mathrm{ArC}), 151.2(\mathrm{ArC}), 140.7(\mathrm{ArC}), 131.9(\mathrm{ArC}), 126.1(\mathrm{ArC}), 125.1(\mathrm{ArC}), 124.5$ (ArC), 120.7 (ArC), 114.6 (ArC), 111.2 (ArC), 63.0 (-CH2-O-), 61.0(-CH2-CH3), 14.6 (CH3); HR-MS (ESI): $m / z$ calcd. for C17H15NO4: 298.1074; and found: $298.1043[\mathrm{M}+\mathrm{H}]^{+}$.

propyl 4-(benzo[d] ]oxazol-2-ylmethoxy)benzoate (5g): White solid; yield, $70.42 \%$; m.p., $44-45{ }^{\circ} \mathrm{C} ;{ }^{1} \mathrm{H}-\mathrm{NMR}$ $(500 \mathrm{MHz}, \mathrm{CDCl} 3) \delta 8.00(\mathrm{~d}, J=8.6 \mathrm{~Hz}, 2 \mathrm{H}, \mathrm{ArH} \times 2), 7.73(\mathrm{~d}, J=6.6 \mathrm{~Hz}, 1 \mathrm{H}, \mathrm{ArH}), 7.52(\mathrm{~d}, J=7.3 \mathrm{~Hz}$, $1 \mathrm{H}, \mathrm{ArH}), 7.33(\mathrm{~m}, 1 \mathrm{H}, \mathrm{ArH}), 7.06(\mathrm{~d}, J=8.6 \mathrm{~Hz}, 2 \mathrm{H}, \mathrm{ArH} \times 2), 5.35(\mathrm{~s}, 2 \mathrm{H},-\mathrm{CH} 2-\mathrm{O}-), 4.22(\mathrm{t}, J=6.6 \mathrm{~Hz}$, $2 \mathrm{H},-\mathrm{CH} 2-\mathrm{CH} 2-\mathrm{CH} 3), 1.74(\mathrm{dd}, J=14.1,7.1 \mathrm{~Hz}, 2 \mathrm{H},-\mathrm{CH} 2-\mathrm{CH} 2-\mathrm{CH} 3), 0.99(\mathrm{t}, J=7.4 \mathrm{~Hz}, 3 \mathrm{H}, \mathrm{CH} 3)$; ${ }^{13} \mathrm{C}-\mathrm{NMR}(125 \mathrm{MHz}, \mathrm{CDCl} 3) \delta 166.3(\mathrm{C}=\mathrm{O}), 161.5$ (-N=C-O-), 160.9 (ArC), 151.1 (ArC), 140.8 (ArC), 131.8 (ArC), $131.7(\mathrm{ArC}), 125.9(\mathrm{ArC}), 124.9(\mathrm{ArC}), 124.8(\mathrm{ArC}), 124.4(\mathrm{ArC}), 120.6(\mathrm{ArC}), 114.5(\mathrm{ArC})$, 111.1 (ArC), 66.5 (-CH2-O-), 62.9 (-CH2-CH2-CH3), 22.3 (-CH2-CH2-CH3), 10.6 (CH3); HR-MS (ESI): $m / z$ calcd. for C18H17NO4: 312.1230; and found: $312.1204[\mathrm{M}+\mathrm{H}]^{+}$.

1-(2-(benzo[d]oxazol-2-ylmethoxy)phenyl)ethanone (5h): Red solid; yield, $65.17 \%$; m.p., $98-100{ }^{\circ} \mathrm{C}$; ${ }^{1} \mathrm{H}-\mathrm{NMR}(500 \mathrm{MHz}, \mathrm{CDCl} 3) \delta 7.76(\mathrm{~m}, 2 \mathrm{H}, \mathrm{ArH} \times 2), 7.57(\mathrm{~m}, 1 \mathrm{H}, \mathrm{ArH}), 7.47(\mathrm{t}, J=7.8 \mathrm{~Hz}, 1 \mathrm{H}$, $\mathrm{ArH}), 7.38(\mathrm{~m}, 2 \mathrm{H}, \mathrm{ArH} \times 2), 7.14(\mathrm{~d}, J=8.3 \mathrm{~Hz}, 1 \mathrm{H}, \mathrm{ArH}), 7.07(\mathrm{t}, J=7.5 \mathrm{~Hz}, 1 \mathrm{H}, \mathrm{ArH}), 5.44(\mathrm{~s}, 2 \mathrm{H}$, CH2), 2.68 (s, 3H, -COCH3); 13C NMR (125 MHz, CDCl3) $\delta 199.7$ (C=O), 161.0 (-N=C-O-), 157.2 (ArC), 151.2 (ArC), 140.7 (ArC), 133.9 (ArC), 130.9 (ArC), $129.3(\operatorname{ArC}), 126.2(\operatorname{ArC}), 125.1(\operatorname{ArC}), 122.2$ (ArC), 120.7 (ArC), 113.1 (ArC), 111.2 (ArC), 63.4 (CH2), 32.2 (CH3); HR-MS (ESI): $m / z$ calcd. for C16H13NO3: 268.0968; and found: $268.0940[\mathrm{M}+\mathrm{H}]^{+}$.

1-(3-(benzo[d]oxazol-2-ylmethoxy)phenyl)ethanone (5i): Yellow solid; yield, 82.4\%; m.p., $71-72{ }^{\circ} \mathrm{C}$; ${ }^{1} \mathrm{H}-\mathrm{NMR}(500 \mathrm{MHz}, \mathrm{CDCl} 3) \delta 7.74(\mathrm{~m}, 1 \mathrm{H}, \mathrm{ArH}), 7.64(\mathrm{~s}, 1 \mathrm{H}, \mathrm{ArH}), 7.56(\mathrm{~d}, J=7.6 \mathrm{~Hz}, 1 \mathrm{H}, \mathrm{ArH}), 7.52$ $(\mathrm{dd}, J=5.4,2.9 \mathrm{~Hz}, 1 \mathrm{H}, \mathrm{ArH}), 7.34(\mathrm{~m}, 3 \mathrm{H}, \mathrm{ArH} \times 3), 7.24(\mathrm{~s}, 1 \mathrm{H}, \mathrm{ArH}), 5.34(\mathrm{~s}, 2 \mathrm{H}, \mathrm{CH} 2), 2.55(\mathrm{~s}, 3 \mathrm{H}$, -COCH3); ${ }^{13} \mathrm{C}-\mathrm{NMR}(125 \mathrm{MHz}, \mathrm{CDCl} 3) \delta 197.3$ (C=O), 160.9 (-N=C-O-), 158.0 (ArC), 150.8 (ArC), 140.7 (ArC), 138.6 (ArC), 129.8 (ArC), $125.6(\mathrm{ArC}), 124.6(\mathrm{ArC}), 122.0(\mathrm{ArC}), 120.4(\mathrm{ArC}), 119.9(\operatorname{ArC}), 113.8$ (ArC), 110.8 (ArC), 62.8 (CH2), 26.6 (CH3); HR-MS (ESI): $m / z$ calcd. for C16H13NO3: 268.0968; and found: $268.0935[\mathrm{M}+\mathrm{H}]^{+}$.

1-(4-(benzo[d]oxazol-2-ylmethoxy)phenyl)ethanone (5j): Yellow solid; yield, 49.44\%; m.p., 110-112 ${ }^{\circ} \mathrm{C}$; ${ }^{1} \mathrm{H}-\mathrm{NMR}(500 \mathrm{MHz}, \mathrm{CDCl}) \delta 7.90(\mathrm{~d}, J=8.7 \mathrm{~Hz}, 2 \mathrm{H}, \mathrm{ArH} \times 2), 7.72(\mathrm{~m}, 1 \mathrm{H}, \mathrm{ArH}), 7.50(\mathrm{~d}, J=6.5 \mathrm{~Hz}$, $1 \mathrm{H}, \mathrm{ArH}), 7.33(\mathrm{~m}, 2 \mathrm{H}, \mathrm{ArH} \times 2), 7.06(\mathrm{~d}, J=8.7 \mathrm{~Hz}, 2 \mathrm{H}, \mathrm{ArH} \times 2), 5.35(\mathrm{~s}, 2 \mathrm{H}, \mathrm{CH} 2), 2.50(\mathrm{~s}, 3 \mathrm{H}$, -COCH3); ${ }^{13} \mathrm{C}-\mathrm{NMR}(125 \mathrm{MHz}, \mathrm{CDCl} 3) \delta 196.7$ (C=O), 161.6 (-N=C-O-), $160.8(\mathrm{ArC}), 151.0(\mathrm{ArC}), 140.7$ (ArC), 131.5 (ArC), $130.8(\mathrm{ArC}), 125.9$ (ArC), $124.9(\mathrm{ArC}), 120.6(\mathrm{ArC}), 114.6(\mathrm{ArC}), 111.1(\mathrm{ArC}), 62.8$ (CH2), 26.4 (CH3); HR-MS (ESI): $m / z$ calcd. for C16H13NO3: 268.0968; and found: $268.0942[\mathrm{M}+\mathrm{H}]^{+}$ 
1-(4-(benzo[d]oxazol-2-ylmethoxy)-2-hydroxyphenyl)ethanone (5k): White solid; yield, 31.8\%; m.p., 98-99 ${ }^{\circ} \mathrm{C} ;{ }^{1} \mathrm{H}-\mathrm{NMR}(500 \mathrm{MHz}, \mathrm{CDCl} 3) \delta 7.75(\mathrm{~d}, J=6.3 \mathrm{~Hz}, 1 \mathrm{H}, \mathrm{ArH}), 7.64(\mathrm{~d}, J=8.7 \mathrm{~Hz}, 1 \mathrm{H}, \mathrm{ArH})$, $7.54(\mathrm{~m}, 1 \mathrm{H}, \mathrm{ArH}), 7.36(\mathrm{~m}, 2 \mathrm{H}, \mathrm{ArH} \times 2), 6.58(\mathrm{~d}, J=10.9 \mathrm{~Hz}, 2 \mathrm{H}, \mathrm{ArH} \times 2), 5.33(\mathrm{~s}, 2 \mathrm{H}, \mathrm{CH} 2), 2.53(\mathrm{~s}$, 3H, -COCH3); ${ }^{13} \mathrm{C}-\mathrm{NMR}(125 \mathrm{MHz}, \mathrm{CDCl} 3) \delta 203.0(\mathrm{C}=\mathrm{O}), 165.2(-\mathrm{N}=\mathrm{C}-\mathrm{O}-), 164.1(\mathrm{ArC}), 160.6(\operatorname{ArC})$, 151.1 (ArC), 140.7 (ArC), 132.8 (ArC), 126.1 (ArC), 125.0 (ArC), 120.7 (ArC), $115.0(\operatorname{ArC}), 111.2(\operatorname{ArC})$, 107.8 (ArC), 102.3 (ArC), 62.9 (CH2), 26.4 (CH3); HR-MS (ESI): m/ $z$ calcd. for C16H13NO4: 284.0917; and found: $284.0888[\mathrm{M}+\mathrm{H}]^{+}$.

4-(benzo[d]oxazol-2-ylmethoxy)-3-methoxybenzaldehyde (51): Yellow solid; yield, 66.43\%; m.p., 100-102 ${ }^{\circ} \mathrm{C}$; ${ }^{1} \mathrm{H}-\mathrm{NMR}(500 \mathrm{MHz}, \mathrm{CDCl} 3) \delta 9.82(\mathrm{~s}, 1 \mathrm{H},-\mathrm{CHO}), 7.72(\mathrm{~d}, J=6.5 \mathrm{~Hz}, 1 \mathrm{H}, \mathrm{ArH}), 7.51(\mathrm{~d}, J=7.1 \mathrm{~Hz}, 1 \mathrm{H}$, ArH), $7.39(\mathrm{~d}, J=12.1 \mathrm{~Hz}, 2 \mathrm{H}, \mathrm{ArH} \times 2), 7.33(\mathrm{dd}, J=5.9,2.7 \mathrm{~Hz}, 2 \mathrm{H}, \mathrm{ArH} \times 2), 7.17(\mathrm{~d}, J=8.1 \mathrm{~Hz}$, 1H, ArH), 5.44 (s, 2H, CH2), 3.90 (s, 3H, CH3); 13C NMR (125 MHz, CDCl3) $\delta 190.9$ (C=O), 160.6 $(-\mathrm{N}=\mathrm{C}-\mathrm{O}-)$, $152.6(\mathrm{ArC}), 151.1(\mathrm{ArC}), 150.3(\mathrm{ArC}), 140.7(\mathrm{ArC}), 131.5(\mathrm{ArC}), 126.4(\mathrm{ArC}), 126.0(\operatorname{ArC})$, 124.9 (ArC), 120.6 (ArC), 113.2 (ArC), 111.2 (ArC), 109.9 (ArC), 63.8 (CH2), $56.2(\mathrm{CH} 3)$; and ESI-MS $m / z: 284.73\left([\mathrm{M}+\mathrm{H}]^{+}\right), 307.03\left([\mathrm{M}+\mathrm{Na}]^{+}\right)$

2-((4-allyl-2-methoxyphenoxy)methyl)benzo[d] thiazole (5m): Brown liquid; yield, $68 \% ;{ }^{1} \mathrm{H}-\mathrm{NMR}(500 \mathrm{MHz}$, CDCl3) $\delta 7.65(\mathrm{dd}, J=94.3,7.1 \mathrm{~Hz}, 1 \mathrm{H}, \mathrm{ArH}), 7.35(\mathrm{~m}, 1 \mathrm{H}, \mathrm{ArH}), 6.92(\mathrm{dd}, J=73.5,8.3 \mathrm{~Hz}, 1 \mathrm{H}, \mathrm{ArH}), 6.71$ $(\mathrm{d}, J=28.9 \mathrm{~Hz}, 2 \mathrm{H}, \mathrm{ArH} \times 2), 5.94(\mathrm{dd}, J=16.2,10.1,6.0 \mathrm{~Hz}, 1 \mathrm{H},-\mathrm{CH}=\mathrm{CH} 2), 5.35(\mathrm{~s}, 2 \mathrm{H},-\mathrm{CH} 2-\mathrm{O}-), 5.07$ (d, $J=17.0 \mathrm{~Hz}, 2 \mathrm{H},-\mathrm{CH}=\mathrm{CH} 2), 3.87(\mathrm{~d}, J=2.9 \mathrm{~Hz}, 3 \mathrm{H}, \mathrm{CH} 3), 3.33(\mathrm{~d}, J=5.4 \mathrm{~Hz}, 2 \mathrm{H},-\mathrm{CH} 2 \mathrm{CH}=\mathrm{CH} 2)$; 13C NMR (125MHz, CDCl3) $\delta 162.0(-\mathrm{N}=\mathrm{C}-\mathrm{O}-), 151.3(\operatorname{ArC}), 150.1(\operatorname{ArC}), 145.8(\operatorname{ArC}), 141.0(\operatorname{ArC})$, $138.1(\mathrm{ArC}), 137.6(\mathrm{ArC}), 135.2(-\mathrm{CH} 2 \mathrm{CH}=\mathrm{CH} 2), 125.7(\mathrm{ArC}), 124.8(\mathrm{ArC}), 120.6(\mathrm{ArC}), 116.1(\mathrm{ArC})$, $115.8(\mathrm{ArC}), 112.7$ (-CH2CH=CH2), $111.2(\mathrm{ArC}), 64.7$ (-CH2-O-), $56.1(\mathrm{CH} 3), 40.1(-\mathrm{CH} 2 \mathrm{CH}=\mathrm{CH} 2)$; HR-MS (ESI): $m / z$ calcd. for C18H17NO3: 296.1281; and found: 296.1256 [M + H] ${ }^{+}$.

2-(phenoxymethyl)benzo[d] thiazole (6a): White solid; yield, 56.02\%; m.p., $74-76{ }^{\circ} \mathrm{C} ;{ }^{1} \mathrm{H}-\mathrm{NMR}(500 \mathrm{MHz}$, CDCl3) $\delta 8.04(\mathrm{~d}, J=8.1 \mathrm{~Hz}, 1 \mathrm{H}, \mathrm{ArH}), 7.90(\mathrm{~d}, J=8.0 \mathrm{~Hz}, 1 \mathrm{H}, \mathrm{ArH}), 7.50(\mathrm{t}, J=7.7 \mathrm{~Hz}, 1 \mathrm{H}, \mathrm{ArH}), 7.40$ $(\mathrm{t}, J=7.6 \mathrm{~Hz}, 1 \mathrm{H}, \mathrm{ArH}), 7.32(\mathrm{t}, J=7.7 \mathrm{~Hz}, 2 \mathrm{H}, \mathrm{ArH} \times 2), 7.05(\mathrm{~d}, J=8.5 \mathrm{~Hz}, 2 \mathrm{H}, \mathrm{ArH} \times 2), 7.02(\mathrm{~m}, 1 \mathrm{H}$, ArH), $5.50(\mathrm{~s}, 2 \mathrm{H}, \mathrm{CH} 2)$; and ESI-MS $m / z: 241.89\left([\mathrm{M}+\mathrm{H}]^{+}\right), 263.87\left([\mathrm{M}+\mathrm{Na}]^{+}\right)$.

2-((4-fluorophenoxy)methyl)benzo[d] thiazole (6b): Yellow solid; yield, 66.41\%; m.p., 86-88 ${ }^{\circ} \mathrm{C} ;{ }^{1} \mathrm{H}-\mathrm{NMR}$ $(500 \mathrm{MHz}, \mathrm{CDCl} 3) \delta 8.05(\mathrm{~d}, J=8.2 \mathrm{~Hz}, 1 \mathrm{H}, \mathrm{ArH}), 7.90(\mathrm{~d}, J=8.0 \mathrm{~Hz}, 1 \mathrm{H}, \mathrm{ArH}), 7.50(\mathrm{dd}, J=11.3$, $4.1 \mathrm{~Hz}, 1 \mathrm{H}, \mathrm{ArH}), 7.41(\mathrm{dd}, J=11.2,4.0 \mathrm{~Hz}, 1 \mathrm{H}, \mathrm{ArH}), 6.98(\mathrm{~d}, J=6.4 \mathrm{~Hz}, 4 \mathrm{H}, \mathrm{ArH} \times 4), 5.46(\mathrm{~s}, 2 \mathrm{H}$, -CH2-O-); and ESI-MS $m / z: 260.11([\mathrm{M}+\mathrm{H}]+), 282.14\left([\mathrm{M}+\mathrm{Na}]^{+}\right)$.

2-((4-chlorophenoxy)methyl)benzo[d]thiazole (6c): Yellow solid; yield, 79.71\%; m.p., 83-86 ${ }^{\circ} \mathrm{C} ;{ }^{1} \mathrm{H}-\mathrm{NMR}$ $(500 \mathrm{MHz}, \mathrm{CDCl} 3) \delta 8.04(\mathrm{~d}, J=8.2 \mathrm{~Hz}, 1 \mathrm{H}, \mathrm{ArH}), 7.88(\mathrm{~d}, J=7.9 \mathrm{~Hz}, 1 \mathrm{H}, \mathrm{ArH}), 7.50(\mathrm{dd}, J=11.3$, $4.1 \mathrm{~Hz}, 1 \mathrm{H}, \mathrm{ArH}), 7.41(\mathrm{t}, J=7.6 \mathrm{~Hz}, 1 \mathrm{H}, \mathrm{ArH}), 7.23(\mathrm{~d}, J=9.0 \mathrm{~Hz}, 2 \mathrm{H}, \mathrm{ArH} \times 2), 6.93(\mathrm{~d}, J=8.9 \mathrm{~Hz}, 2 \mathrm{H}$, $\mathrm{ArH} \times 2), 5.43(\mathrm{~s}, 2 \mathrm{H},-\mathrm{CH} 2-\mathrm{O}-)$; and ESI-MS $m / z: 275.81\left([\mathrm{M}]^{+}\right)$.

4-(benzo[d]thiazol-2-ylmethoxy)benzaldehyde (6d): Yellow solid; yield, 50.19\%; m.p., $106-10{ }^{\circ} \mathrm{C} ;{ }^{1} \mathrm{H}-\mathrm{NMR}$ $(500 \mathrm{MHz}, \mathrm{CDCl} 3) \delta 9.90(\mathrm{~s}, 1 \mathrm{H},-\mathrm{CHO}), 8.07(\mathrm{~d}, J=8.1 \mathrm{~Hz}, 1 \mathrm{H}, \mathrm{ArH}), 7.92(\mathrm{~d}, J=8.0 \mathrm{~Hz}, 1 \mathrm{H}, \mathrm{ArH})$, $7.87(\mathrm{~d}, J=8.6 \mathrm{~Hz}, 2 \mathrm{H}, \mathrm{ArH} \times 2), 7.53(\mathrm{t}, J=7.3 \mathrm{~Hz}, 1 \mathrm{H}, \mathrm{ArH}), 7.45(\mathrm{t}, J=7.6 \mathrm{~Hz}, 1 \mathrm{H}, \mathrm{ArH}), 7.16$ $(\mathrm{d}, J=8.5 \mathrm{~Hz}, 2 \mathrm{H}, \mathrm{ArH} \times 2), 5.60(\mathrm{~s}, 2 \mathrm{H}, \mathrm{CH} 2) ; 13 \mathrm{C} \mathrm{NMR}(125 \mathrm{MHz}, \mathrm{CDCl} 3) \delta 191.1(\mathrm{C}=\mathrm{O}), 167.7$ (-N=C-S-), 162.8 (ArC), 152.4 (ArC), 135.0 (ArC), 132.7 (ArC), 132.4 (ArC), 131.2 (ArC), $130.0(\operatorname{ArC})$, 126.9 (ArC), $126.0(\mathrm{ArC}), 123.3(\mathrm{ArC}), 122.2(\mathrm{ArC}), 116.3(\mathrm{ArC}), 115.5(\mathrm{ArC})$, and 67.9 (CH2). ESI-MS $m / z: 270.01\left([\mathrm{M}+\mathrm{H}]^{+}\right)$and $292.00\left([\mathrm{M}+\mathrm{Na}]^{+}\right)$.

methyl 4-(benzo[d]thiazol-2-ylmethoxy)benzoate (6e): Yellow solid; yield, 25.42\%; m.p., $116-118{ }^{\circ} \mathrm{C}$; ${ }^{1} \mathrm{H}-\mathrm{NMR}(500 \mathrm{MHz}, \mathrm{CDCl} 3) \delta 8.04(\mathrm{~d}, J=8.2 \mathrm{~Hz}, 1 \mathrm{H}, \mathrm{ArH}), 8.01(\mathrm{~s}, 1 \mathrm{H}, \mathrm{ArH}), 8.00(\mathrm{~s}, 1 \mathrm{H}, \mathrm{ArH})$, $7.88(\mathrm{~d}, J=7.9 \mathrm{~Hz}, 1 \mathrm{H}, \mathrm{ArH}), 7.50(\mathrm{t}, J=7.5 \mathrm{~Hz}, 1 \mathrm{H}, \mathrm{ArH}), 7.40(\mathrm{t}, J=7.4 \mathrm{~Hz}, 1 \mathrm{H}, \operatorname{ArH}), 7.06(\mathrm{~d}$, $J=8.3 \mathrm{~Hz}, 2 \mathrm{H}, \mathrm{ArH} \times 2), 5.53(\mathrm{~s}, 2 \mathrm{H}, \mathrm{CH} 2), 3.87(\mathrm{~s}, 3 \mathrm{H}, \mathrm{CH} 3)$; and ESI-MS $m / z: 300.68\left([\mathrm{M}+\mathrm{H}]^{+}\right)$, $322.04\left([\mathrm{M}+\mathrm{Na}]^{+}\right)$. 
ethyl 4-(benzo[d] thiazol-2-ylmethoxy)benzoate (6f): White solid; yield, 36.42\%; m.p., $118-120{ }^{\circ} \mathrm{C} ;{ }^{1} \mathrm{H}-\mathrm{NMR}$ $(500 \mathrm{MHz}, \mathrm{CDCl} 3) \delta 8.04(\mathrm{~d}, J=8.2 \mathrm{~Hz}, 1 \mathrm{H}, \mathrm{ArH}), 8.02(\mathrm{~s}, 1 \mathrm{H}, \mathrm{ArH}), 8.01(\mathrm{~s}, 1 \mathrm{H}, \mathrm{ArH}), 7.89(\mathrm{~d}, J=8.0 \mathrm{~Hz}$, $1 \mathrm{H}, \mathrm{ArH}), 7.50(\mathrm{t}, J=7.7 \mathrm{~Hz}, 1 \mathrm{H}, \mathrm{ArH}), 7.41(\mathrm{t}, J=7.6 \mathrm{~Hz}, 1 \mathrm{H}, \mathrm{ArH}), 7.05(\mathrm{~d}, J=8.8 \mathrm{~Hz}, 2 \mathrm{H}, \mathrm{ArH} \times$ 2), $5.54(\mathrm{~s}, 2 \mathrm{H},-\mathrm{CH} 2-\mathrm{O}-), 4.34$ (q, J = 7.1 Hz, 2H, -CH2-CH3), 1.36 (t, $J=7.1 \mathrm{~Hz}, 3 \mathrm{H}, \mathrm{CH} 3) ; 13 \mathrm{C}$ NMR

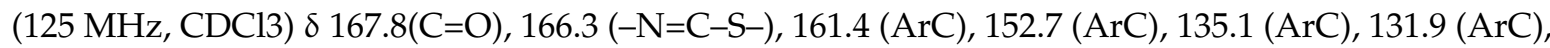
126.6 (ArC), 125.7 (ArC), 124.4 (ArC), 123.3 (ArC), 122.1 (ArC), 114.7 (ArC), 67.9 (-CH2-O-), 61.0 (-CH2-CH3), $14.6(\mathrm{CH} 3)$; and ESI-MS m/z: $314.17([\mathrm{M}+\mathrm{H}]+), 336.75\left([\mathrm{M}+\mathrm{Na}]^{+}\right)$.

propyl 4-(benzo[d]thiazol-2-ylmethoxy)benzoate (6g): White solid; yield, 48.93\%; m.p., 106-108 ${ }^{\circ} \mathrm{C}$; ${ }^{1} \mathrm{H}-\mathrm{NMR}(500 \mathrm{MHz}, \mathrm{CDCl}) \delta 8.04(\mathrm{~d}, J=12.0 \mathrm{~Hz}, 2 \mathrm{H}, \mathrm{ArH} \times 2), 8.01(\mathrm{~s}, 1 \mathrm{H}, \mathrm{ArH}), 7.89(\mathrm{~d}, J=8.0 \mathrm{~Hz}$, $1 \mathrm{H}, \mathrm{ArH}), 7.52(\mathrm{~d}, J=7.4 \mathrm{~Hz}, 1 \mathrm{H}, \mathrm{ArH}), 7.41(\mathrm{t}, J=7.6 \mathrm{~Hz}, 1 \mathrm{H}, \mathrm{ArH}), 7.06(\mathrm{~d}, J=8.6 \mathrm{~Hz}, 2 \mathrm{H}, \mathrm{ArH} \times$ 2), $5.54(\mathrm{~s}, 2 \mathrm{H},-\mathrm{CH} 2-\mathrm{O}-), 4.25(\mathrm{t}, J=6.6 \mathrm{~Hz}, 2 \mathrm{H},-\mathrm{CH} 2-\mathrm{CH} 2-\mathrm{CH} 3), 1.77$ (dd, $J=14.2,7.1 \mathrm{~Hz}, 2 \mathrm{H}$, -CH2-CH2-CH3), 1.01 (t, J = 7.4 Hz, 3H, CH3); 13C NMR (125 MHz, CDCl3) $\delta 167.8(\mathrm{C}=\mathrm{O}), 166.4$ (-N=C-S-), 161.5 (ArC), 152.9 (ArC), 135.2 (ArC), 131.9 (ArC), $126.6(\operatorname{ArC}), 125.7$ (ArC), 124.5 (ArC), 123.4 (ArC), 122.1 (ArC), 114.8 (ArC), 68.0 (-CH2-O-), 66.6 (-CH2-CH2-CH3), 22.4 (-CH2-CH2-CH3), 10.7 (CH3); HR-MS (ESI): $m / z$ calcd. for C18H17NO3S: 328.1002; and found: $328.0972[\mathrm{M}+\mathrm{H}]^{+}$.

1-(2-(benzo[d]thiazol-2-ylmethoxy)phenyl)ethanone (6h): Yellow solid; yield, 80.21\%; m.p., 89-90 ${ }^{\circ} \mathrm{C}$; ${ }^{1} \mathrm{H}-\mathrm{NMR}(500 \mathrm{MHz}, \mathrm{CDCl} 3) \delta 7.91(\mathrm{~m}, 1 \mathrm{H}, \mathrm{ArH}), 7.77(\mathrm{dd}, J=7.6,1.4 \mathrm{~Hz}, 1 \mathrm{H}, \mathrm{ArH}), 7.49(\mathrm{~m}, 3 \mathrm{H}, \mathrm{ArH}$ $\times 3), 7.34(\mathrm{~m}, 1 \mathrm{H}, \mathrm{ArH}), 7.06(\mathrm{~d}, J=8.7 \mathrm{~Hz}, 2 \mathrm{H}, \mathrm{ArH} \times 2), 5.57(\mathrm{~s}, 2 \mathrm{H}, \mathrm{CH} 2), 2.74(\mathrm{~s}, 3 \mathrm{H},-\mathrm{COCH} 3) ;$ and ESI-MS $m / z: 284.06\left([\mathrm{M}+\mathrm{H}]^{+}\right), 306.10\left([\mathrm{M}+\mathrm{Na}]^{+}\right)$.

1-(3-(benzo[d]thiazol-2-ylmethoxy)phenyl)ethanone (6i): Yellow solid; yield, 67.84\%; m.p., 107-108 ${ }^{\circ} \mathrm{C}$; ${ }^{1} \mathrm{H}-\mathrm{NMR}(500 \mathrm{MHz}, \mathrm{CDCl} 3) \delta 8.04(\mathrm{~d}, J=8.2 \mathrm{~Hz}, 1 \mathrm{H}, \mathrm{ArH}), 7.90(\mathrm{~d}, J=8.0 \mathrm{~Hz}, 1 \mathrm{H}, \mathrm{ArH}), 7.65(\mathrm{~s}, 1 \mathrm{H}$, $\mathrm{ArH}), 7.60(\mathrm{~d}, J=7.6 \mathrm{~Hz}, 1 \mathrm{H}, \mathrm{ArH}), 7.51(\mathrm{t}, J=7.5 \mathrm{~Hz}, 1 \mathrm{H}, \mathrm{ArH}), 7.41(\mathrm{t}, J=7.9 \mathrm{~Hz}, 2 \mathrm{H}, \operatorname{ArH} \times 2)$, $7.23(\mathrm{t}, J=6.8 \mathrm{~Hz}, 1 \mathrm{H}, \mathrm{ArH}), 5.54(\mathrm{~s}, 2 \mathrm{H}, \mathrm{CH} 2), 2.60(\mathrm{~s}, 3 \mathrm{H},-\mathrm{COCH} 3)$; HR-MS (ESI): $m / z$ calcd. for C16H13NO2S: 284.0740; and found: $284.0708[\mathrm{M}+\mathrm{H}]^{+}$.

1-(4-(benzo[d]thiazol-2-ylmethoxy)phenyl)ethanone (6j): White solid; yield, $61.13 \%$; m.p., $148-150{ }^{\circ} \mathrm{C}$; ${ }^{1} \mathrm{H}-\mathrm{NMR}(500 \mathrm{MHz}, \mathrm{CDCl} 3) \delta 8.05(\mathrm{~d}, J=8.0 \mathrm{~Hz}, 1 \mathrm{H}, \mathrm{ArH}), 7.96(\mathrm{~d}, J=8.7 \mathrm{~Hz}, 2 \mathrm{H}, \mathrm{ArH} \times 2), 7.90(\mathrm{~d}$, $J=8.2 \mathrm{~Hz}, 1 \mathrm{H}, \mathrm{ArH}), 7.53(\mathrm{~d}, J=7.3 \mathrm{~Hz}, 1 \mathrm{H}, \mathrm{ArH}), 7.42(\mathrm{t}, J=7.6 \mathrm{~Hz}, 1 \mathrm{H}, \mathrm{ArH}), 7.09(\mathrm{~d}, J=8.7 \mathrm{~Hz}$, $2 \mathrm{H}, \mathrm{ArH} \times 2), 5.56(\mathrm{~s}, 2 \mathrm{H}, \mathrm{CH} 2), 2.56(\mathrm{~s}, 3 \mathrm{H},-\mathrm{COCH})$; and ESI-MS $m / z: 284.15\left([\mathrm{M}+\mathrm{H}]^{+}\right), 306.08$ $\left([\mathrm{M}+\mathrm{Na}]^{+}\right)$.

1-(4-(benzo[d]thiazol-2-ylmethoxy)-2-hydroxyphenyl)ethanone (6k): White solid; yield, 37.46\%; m.p., 128-130 ${ }^{\circ} \mathrm{C}$; $1 \mathrm{H}$ NMR $(500 \mathrm{MHz}, \mathrm{CDCl} 3) \delta 8.05(\mathrm{~d}, J=8.2 \mathrm{~Hz}, 1 \mathrm{H}, \mathrm{ArH}), 7.91(\mathrm{~d}, J=8.0 \mathrm{~Hz}, 1 \mathrm{H}$, $\mathrm{ArH}), 7.68(\mathrm{~s}, 1 \mathrm{H}, \mathrm{ArH}), 7.52(\mathrm{t}, J=7.7 \mathrm{~Hz}, 1 \mathrm{H}, \mathrm{ArH}), 7.43(\mathrm{t}, J=7.6 \mathrm{~Hz}, 1 \mathrm{H}, \mathrm{ArH}), 6.58(\mathrm{~m}, 2 \mathrm{H}, \mathrm{ArH}$ $\times 2), 6.40(\mathrm{~d}, J=12.5 \mathrm{~Hz}, 1 \mathrm{H}, \mathrm{ArH}), 5.53(\mathrm{~s}, 2 \mathrm{H}, \mathrm{CH} 2), 2.55(\mathrm{~d}, J=9.5 \mathrm{~Hz}, 3 \mathrm{H},-\mathrm{COCH}) ; 13 \mathrm{C}$ NMR (125 MHz, CDCl3) \& 203.1(C=O), 167.6 (-N=C-S-), 165.3 (ArC), 164.1 (ArC), 152.6 (ArC), 133.3 (ArC), 132.9 (ArC), 126.8 (ArC), 125.9 (ArC), 123.3 (ArC), 122.1 (ArC), 115.1 (ArC), 107.8 (ArC), 102.8 (ArC), 67.8 (CH2), 26.5 (CH3); HR-MS (ESI): $m / z$ calcd. for C16H13NO3S: 300.0689; and found: 300.0662 [M + $\mathrm{H}]^{+}$.

4-(benzo[d] thiazol-2-ylmethoxy)-3-methoxybenzaldehyde (61): Yellow solid; yield, $46.15 \%$; m.p., $110-112{ }^{\circ} \mathrm{C}$; ${ }^{1} \mathrm{H}-\mathrm{NMR}(500 \mathrm{MHz}, \mathrm{CDCl} 3) \delta 9.84(\mathrm{~s}, 1 \mathrm{H},-\mathrm{CHO}), 8.05(\mathrm{~d}, J=8.0 \mathrm{~Hz}, 1 \mathrm{H}, \mathrm{ArH}), 7.89(\mathrm{~d}, J=7.8 \mathrm{~Hz}, 1 \mathrm{H}$, $\operatorname{ArH}), 7.51(\mathrm{t}, J=7.6 \mathrm{~Hz}, 1 \mathrm{H}, \mathrm{ArH}), 7.45(\mathrm{~s}, 1 \mathrm{H}, \mathrm{ArH}), 7.41(\mathrm{dd}, J=14.6,7.7 \mathrm{~Hz}, 2 \mathrm{H}, \mathrm{ArH} \times 2), 7.12(\mathrm{~d}$, $J=8.0 \mathrm{~Hz}, 1 \mathrm{H}, \mathrm{ArH}), 5.65(\mathrm{~s}, 1 \mathrm{H}), 3.97(\mathrm{~s}, 3 \mathrm{H})$; and ESI-MS m/z: $300.37\left([\mathrm{M}+\mathrm{H}]^{+}\right), 322.78\left(\left[\mathrm{M}+\mathrm{Na}^{+}\right)\right.$.

2-((4-allyl-2-methoxyphenoxy)methyl)benzo[d]oxazole (6m): White solid; yield, 41.8\%; m.p., $54-56{ }^{\circ} \mathrm{C}$; ${ }^{1} \mathrm{H}-\mathrm{NMR}(500 \mathrm{MHz}, \mathrm{CDCl} 3) \delta 8.04(\mathrm{~d}, J=8.1 \mathrm{~Hz}, 1 \mathrm{H}, \mathrm{ArH}), 7.88(\mathrm{~d}, J=7.9 \mathrm{~Hz}, 1 \mathrm{H}, \mathrm{ArH}), 7.49$ (m, $1 \mathrm{H}, \mathrm{ArH}), 7.39(\mathrm{dd}, J=11.2,4.0 \mathrm{~Hz}, 1 \mathrm{H}, \mathrm{ArH}), 6.95(\mathrm{~d}, J=8.1 \mathrm{~Hz}, 1 \mathrm{H}, \mathrm{ArH}), 6.77(\mathrm{~s}, 1 \mathrm{H}, \mathrm{ArH}), 6.68(\mathrm{~d}$, $J=8.0 \mathrm{~Hz}, 1 \mathrm{H}, \mathrm{ArH} \times 2), 5.94(\mathrm{dd}, J=16.9,10.1 \mathrm{~Hz}, 1 \mathrm{H},-\mathrm{CH}=\mathrm{CH} 2), 5.54(\mathrm{~s}, 2 \mathrm{H},-\mathrm{CH} 2-\mathrm{O}-), 5.09(\mathrm{~d}$, $J=1.3 \mathrm{~Hz}, 1 \mathrm{H},-\mathrm{CH}=\mathrm{CH} 2), 5.06(\mathrm{~d}, J=0.9 \mathrm{~Hz}, 1 \mathrm{H}, \mathrm{CH}=\mathrm{CH} 2), 3.91(\mathrm{~s}, 3 \mathrm{H}, \mathrm{CH} 3), 3.33(\mathrm{~d}, J=6.6 \mathrm{~Hz}, 2 \mathrm{H}$, -CH2CH=CH2); ${ }^{13} \mathrm{C}-\mathrm{NMR}(125 \mathrm{MHz}, \mathrm{CDCl} 3) \delta 169.9$ (-N=C-S-), $152.5(\mathrm{ArC}), 150.1(\mathrm{ArC}), 145.9(\operatorname{ArC})$, 
137.6 (ArC), 135.1 (-CH2CH=CH2), $126.5(\operatorname{ArC}), 125.5(\operatorname{ArC}), 123.1(\operatorname{ArC}), 122.1(\operatorname{ArC}), 120.8(\operatorname{ArC})$, 116.1 (ArC), 115.6 (-CH2CH=CH2), 113.0 (ArC), 69.6 (-CH2-O-), $56.2(\mathrm{CH} 3), 40.0(-\mathrm{CH} 2 \mathrm{CH}=\mathrm{CH} 2)$; HR-MS (ESI): $m / z$ calcd. for C18H17NO2S: 312.1053; and found: $312.1024[\mathrm{M}+\mathrm{H}]^{+}$.

\subsection{Antifungal Bioassay}

According to our previous research [32-34], the mycelium growth rate method was employed to assess the fungicidal activities of the synthetic compounds against eight plant pathogenic fungi (Fusarium oxysporum $f$. sp. niveum, Fusarium. graminearum, Fusarium. solani, Alternaria solani, Colletotrichum gloeosporioides, Valsa mali, Magnaporthe oryzae, and Botrytis cinerea), which were provided by the Institute of Plant Disease, Northwest A and F University, China. The strains were retrieved from the storage tube and cultured for two weeks at $28 \pm 0.5^{\circ} \mathrm{C}$ on a potato dextrose agar (PDA).

The specific methods are based on the literature [1]: PDA medium was prepared in the conical flasks and sterilized. The tested compounds were dissolved in acetone, making five concentrations with the gradients of $100,50,25,12.5$, and $6.25 \mu \mathrm{g} / \mathrm{mL}$, before mixing with molten agar at $55^{\circ} \mathrm{C}$. The mixture was then poured into sterilized Petri dishes. The tested fungi were incubated in PDA at $28 \pm 0.5{ }^{\circ} \mathrm{C}$ for one week for the antifungal assays. A hole puncher with a diameter of four $\mathrm{mm}$ was used to cut culture medium and vaccinated to the center of the PDA Petri dishes with a sterilized inoculation needle. The inoculated Petri dishes were incubated at $28 \pm 0.5^{\circ} \mathrm{C}$ for three-to-four days until the mycelia grew completely. Commercially available fungicide hymexazol was used as the positive control, while the solution of equal concentration of acetone was used as a negative control. Three repetitions were conducted for each sample and the diameters of the mycelia were measured four times by cross bracketing method. The inhibition rate was calculated according to the formula:

$$
\text { Inhibition rate }(\%)=(C-T) /(C-4 \mathrm{~mm}) \times 100 \%
$$

where $C$ is the average diameter of mycelia in the blank test, and $\mathrm{T}$ is the average diameter of mycelia on treated PDA with those compounds.

The inhibition ratio of those compounds at the concentration of $100 \mu \mathrm{g} / \mathrm{mL}$ was shown in Table 1. The compounds with more than $60 \%$ inhibition rates were selected for further comparison and $\mathrm{IC}_{50}$ (median inhibitory concentration) values of rates were determined. The experimental data of the fungicidal activities were analyzed using software of excel from Windows to give the results of $\mathrm{IC}_{50}$ values, as shown in Table 2.

\subsection{Molecular Docking Studies}

The crystal structure the lipid transfer protein sec14p from Saccharomyces cerevisiae (PDB 6F0E) was provided from the Brookhaven protein data bank (PDB; http://www.rcsb.org/pdb). Docking studies were performed by using AutoDock 4.2 software (The Scripps Research Institute, California, CA, USA), as in our previous studies [35]. The preparations relevant to Autodock docking were done using the Autodock Tools. The grid box $(40 \times 40 \times 40)$ was set according to the active site. The docking parameters consisted of setting the population size to 150 , the number of generations to 270,000 , and the number of evaluations to $25,000,000$ while the number of docking runs was set to 40 with other default values during each docking run. Docking calculations were carried with the Lamarkian Genetic Algorithm (LGA). The analysis of results was carried out by USCF Chimera software (the Computer Graphics Laboratory, California, CA, USA), which was downloaded from http://www.cgl.ucsf.edu/chimera. 


\section{Conclusions}

In the present study, a series of benzoxazole and benzothiazole derivatives were prepared and their fungicidal activities against eight plant pathogens were tested. Most of the test compounds, i.e., $\mathbf{5 a}, \mathbf{5} \mathbf{b}, \mathbf{5 h}$, and $\mathbf{5 i}$, were found to be more active against two fungi, F. solani and B. cinerea, than the other six organisms. $\mathbf{5 a}, \mathbf{5} \mathbf{b}, \mathbf{5} \mathbf{h}$, and $\mathbf{5 i}$ were found to be most efficient antifungal compounds and may be new leads for the development of new fungicides. Furthermore, from the present results, it appears that benzoxazoles have an advantage over benzothiazoles as a template in antifungal potency.

Supplementary Materials: The following are available on line. ${ }^{1} \mathrm{H}-\mathrm{NMR},{ }^{13} \mathrm{C}-\mathrm{NMR}$ and mass spectroscopy (MS) of compounds $5 \mathbf{a}-\mathbf{m}$ and $6 \mathbf{a}-\mathbf{m}$.

Author Contributions: J.-M.G. and A.-L.Z. designed and observed the proposal and contributed to data analysis and interpretation. B.L. performed the experiments and conducted the biological study. D.L. performed the molecular docking studies and wrote the molecular docking sections of the paper. B.L. wrote the manuscript. J.-M.G. and D.L. revised the manuscript. All authors discussed the results and implications, and commented on the manuscript at all stages.

Funding: This work was supported by the grants from the National Natural Science Foundation of China (No. 21502152, 21372185, 31371958), the Program of UnifiedPlanning Innovation Engineering of Science \& Technology in Shaanxi Province (No. 2015KTCQ02-14), Chinese Universities Scientific Fund (No. 2452016092), and the Natural Science Foundation of Shaanxi Province (No. 2014JQ2075).

Acknowledgments: We would like to thank Ji-Jun Chen for measurement of HRMS of new compounds.

Conflicts of Interest: The authors declare no competing financial interest.

\section{References}

1. Xiao, J.; Zhang, Q.; Gao, Y.Q.; Tang, J.J.; Zhang, A.L.; Gao, J.-M. Secondary metabolites from the endophytic Botryosphaeria dothidea of Melia azedarach and their antifungal, antibacterial, antioxidant, and cytotoxic activities. J. Agric. Food Chem. 2014, 62, 3584-3590. [PubMed]

2. Meepagala, K.M.; Kuhajek, J.M.; Sturtz, G.D.; Wedge, D.E.; Vulgarone, B. The antifungal constituent in the steam-distilled fraction of Artemisia douglasiana. J. Chem. Ecol. 2003, 29, 1771-1780. [PubMed]

3. Pérez-García, A.; Romero, D.; de Vicente, A. Plant protection and growth stimulation by microorganisms: Biotechnological applications of Bacilli in agriculture. Curr. Opin. Biotechnol. 2011, 22, 187-193. [CrossRef] [PubMed]

4. Muto, M.; Takahashi, H.; Ishihara, K.; Yuasa, H.; Huang, J.W. Antimicrobial activity of medicinal plant extracts used by indigenous people in Taiwan. Plant. Pathol. Bull. 2005, 14, 13-24.

5. Noolvi, M.N.; Patel, H.M.; Kaur, M. Benzothiazoles: Search for anticancer agents. Eur. J. Med. Chem. 2012, 54, 447-462. [CrossRef] [PubMed]

6. Hutchinson, I.; Jennings, S.A.; Vishnuvajjala, B.R.; Westwell, A.D.; Stevens, M.F. Antitumor benzothizoles 16. Synthesis and pharmaceutical properties of antitumor 2(4-aminophenyl)benzothizoles amino acid prodrugs. J. Med. Chem 2002, 45, 744-747. [PubMed]

7. Jiang, L.L.; Zuo, Y.; Wang, Z.F.; Tan, Y.; Wu, Q.Y.; Xi, Z.; Yang, G.F. Design and syntheses of novel $N$-(benzothiazol-5-yl)-4,5,6,7-tetrahydro-1H-isoindole-1,3(2H)-dione and N-(benzothiazol-5-yl) isoindoline-1,3-dione as potent protoporphyrinogen oxidase inhibitors. J. Agric. Food Chem. 2011, 59, 6172-6179. [CrossRef] [PubMed]

8. Burger, A.; Sawhney, S.N. Antimalarials III. Benzothiazole amino alcohols. J. Med. Chem. 1968, 11, $270-273$. [CrossRef] [PubMed]

9. Musser, J.H.; Kubrak, D.M.; Chang, J.; DiZio, S.M.; Hite, M.; Hand, J.M.; Lewis, A.J. Leukotriene $\mathrm{D}_{4}$ antagonists and 5-lipoxygenase inhibitors. synthesis of benzoheterocyclic [(methoxyphenyl)amino] oxoalkanoic acid esters. J. Med. Chem. 1987, 30, 400-405. [PubMed]

10. Sheng, C.; Xu, H.; Wang, W.; Cao, Y.; Dong, G.; Wang, S.; Che, X.; Ji, H.; Miao, Z.; Yao, J.; Zhang, W. Design, synthesis and antifung al activity of isosteric analogues of benzoheterocyclic $N$-myristoyltransferase inhibitors. Eur. J. Med. Chem. 2010, 45, 3531-3540. [CrossRef] [PubMed] 
11. Saeed, S.; Rashid, N.; Jones, P.G.; Ali, M.; Hussain, R. Synthesis, characterization and biological evaluation of some thiourea derivatives bearing benzothiazole moiety as potential antimicrobial and anticancer agents. Eur. J. Med. Chem. 2010, 45, 1323-1331. [CrossRef] [PubMed]

12. Kakkar, S.; Tahlan, S.; Lim, S.M.; Ramasamy, K.; Mani, V.; Shah, S.A.A.; Narasimhan, B. Benzoxazole derivatives: Design, synthesis and biological evaluation. Chem. Cent. J. 2018, 12, 92. [CrossRef] [PubMed]

13. Li, D.; Luong, T.T.M.; Dan, W.-J.; Ren, Y.; Nien, H.X.; Zhang, A.-L.; Gao, J.-M. Natural products as sources of new fungicides (IV): Synthesis and biological evaluation of isobutyrophenone analogs as potential inhibitors of class-II fructose-1,6-bisphosphate aldolase. Bioorgan. Med. Chem. 2018, 26, 386-393. [CrossRef] [PubMed]

14. Shi, W.; Dan, W.-J.; Tang, J.-J.; Zhang, Y.; Nandinsuren, T.; Zhang, A.-L.; Gao, J.-M. Natural products as sources of new fungicides (III): Antifungal activity of 2,4-dihydroxy-5-methylacetophenone derivatives. Bioorg. Med. Chem. Lett. 2016, 26, 2156-2158. [CrossRef] [PubMed]

15. Kosaka, T.; Wakabayashi, T. Synthesis of 2-(4-aryl-1E,3E-butadienyl) benzoxazoleby the horner-wadsworthemmons reaction. Heterocycles 1995, 41, 477-485. [CrossRef]

16. Burkholder, C.R.; Dolbier, W.R., Jr.; Médebielle, M. Synthesis and reactivity of halogeno-difluoromethyl aromatics and heterocycles: Application to the synthesis of gem-difluorinated bioactive compounds. J. Fluorine Chem. 2001, 109, 39-48. [CrossRef]

17. Zhao, C.; Ma, S. Recent Advances in The Discovery of N-Myristoyltransferase Inhibitors. ChemMedChem 2014, 9, 2425-2437. [CrossRef] [PubMed]

18. Popp, F.D.; McEwen, W.E. Polyphosphoric acids as a reagent in organic chemistry. Chem. Rev. 1958, 58, 321-401. [CrossRef]

19. So, Y.H.; Heeschen, J.P. Mechanism of polyphosphoric acid and phosphorus pentoxide-methanesulfonic acid as synthetic reagents for benzoxazole formation. J. Org. Chem. 1997, 62, 3552-3561. [CrossRef]

20. Sheng, C.; Che, X.; Wang, W.; Wang, S.; Cao, Y.; Yao, J.; Miao, Z.; Zhang, W. Design and synthesis of antifungal benzoheterocyclic derivatives by scaffold hopping. Eur. J. Med. Chem. 2011, 46, 1706-1712. [CrossRef] [PubMed]

21. Peprah, K.; Zhu, X.Y.; Eyunni, S.V.; Etukala, J.R.; Setola, V.; Roth, B.L.; Ablordeppey, S.Y. Structure-activity relationship studies of SYA 013, a homopiperazine analog of haloperidol. Bioorg. Med. Chem. 2012, 20, 1671-1678. [CrossRef] [PubMed]

22. Hou, J.; Li, Z.; Fang, Q.; Feng, C.; Zhang, H.; Guo, W.; Wang, H.; Gu, G.; Tian, Y.; Liu, P.; et al. Discovery and extensive in vitro evaluations of NK-HDAC-1: A chiral histone deacetylase inhibitor as a promising lead. J. Med. Chem. 2012, 55, 3066-3075. [CrossRef] [PubMed]

23. Hori, M.; Kataoka, T. Studies on benzothiazoline derivatives. III. Reactions of 2,2-disubstituted benzothiazolines with haloacyl halides or acid anhydrides. Chem. Pharm. Bull. 1979, 27, 1973-1981. [CrossRef]

24. Sharghi, H.; Asemani, O. Methanesulfonic Acid $/ \mathrm{SiO}_{2}$ as an efficient combination for the synthesis of 2-substituted aromatic and aliphatic benzothiazoles from carboxylic acids. Synth. Commun. 2009, 39, 860-867. [CrossRef]

25. Morais, G.R.; Miranda, H.V.; Santos, I.C.; Santos, I; Outeiro, T.F.; Paulo, A. Synthesis and in vitro evaluation of fluorinated styryl benzazoles as amyloid-probes. Bioorg. Med. Chem. 2011, 19, 7698-7710. [CrossRef] [PubMed]

26. Njoya, Y.; Gellis, A.; Crozet, M.P.; Vanelle, P. Efficient synthesis of new 6-nitrobenzothiazoles using microwave irradiation. Sulfur Lett. 2003, 26, 67-75. [CrossRef]

27. Gellis, A.; Boufatah, N.; Vanelle, P. Rapid microwave-promoted synthesis of new sulfonylmethylbenzothiazoles in water. Green Chem. 2006, 8, 483-487. [CrossRef]

28. Lee, A.; Lee, K.; Kim, D. Using reverse docking for target identification and its applications for drug discovery. Expert Opin. Drug Dis. 2016, 11, 707-715. [CrossRef] [PubMed]

29. Nile, A.H.; Tripathi, A.; Yuan, P.; Mousley, C.J.; Suresh, S.; Wallace, I.M.; Shah, S.D.; Pohlhaus, D.T.; Temple, B.; Nislow, C.; et al. PITPs as targets for selectively interfering with phosphoinositide signaling in cells. Nat. Chem. Biol. 2013, 10, 76. [CrossRef] [PubMed]

30. Pries, V.; Nöcker, C.; Khan, D.; Johnen, P.; Hong, Z.; Tripathi, A.; Keller, A.-L.; Fitz, M.; Perruccio, F.; Filipuzzi, I.; et al. Target Identification and Mechanism of Action of Picolinamide and Benzamide Chemotypes with Antifungal Properties. Cell. Chem. Biol. 2018, 25, 279-290. [CrossRef] [PubMed] 
31. Filipuzzi, I.; Cotesta, S.; Perruccio, F.; Knapp, B.; Fu, Y.; Studer, C.; Pries, V.; Riedl, R.; Helliwell, S.B.; Petrovic, K.T.; et al. High-Resolution Genetics Identifies the Lipid Transfer Protein Sec14p as Target for Antifungal Ergolines. PLoS Genet. 2016, 12. [CrossRef] [PubMed]

32. Nandinsuren, T.; Shi, W.; Zhang, A.L.; Bai, Y.B.; Gao, J.-M. Natural products as sources of new fungicides (II): Antiphytopathogenic activity of 2,4-dihydroxyphenyl ethanone derivatives. Nat. Prod. Res. 2016, 30, 1166-1169. [CrossRef] [PubMed]

33. Xiao, J.; Zhang, Q.; Gao, Y.-Q.; Shi, X.-W.; Gao, J.-M. Antifungal and antibacterial metabolites from an endophytic Aspergillus sp. associated with Melia azedarach. Nat. Prod. Res. 2014, 28, 1388-1392. [CrossRef] [PubMed]

34. Li, X.-J.; Zhang, Q.; Zhang, A.-L.; Gao, J.-M. Metabolites from Aspergillus fumigatus, an endophytic fungus associated with Melia azedarach, and their antifungal, antifeedant, and toxic activities. J. Agric. Food Chem. 2012, 60, 3424-3431. [CrossRef] [PubMed]

35. Li, D.; Chi, B.; Wang, W.-W.; Gao, J.-M.; Wan, J. Exploring the possible binding mode of trisubstituted benzimidazoles analogues in silico for novel drug designtargeting Mtb FtsZ. Med. Chem. Res. 2017, 26, 153-169. [CrossRef]

Sample Availability: Samples of the compounds the benzoxazole and benzothiazole derivatives are available from the authors.

(C) 2018 by the authors. Licensee MDPI, Basel, Switzerland. This article is an open access article distributed under the terms and conditions of the Creative Commons Attribution (CC BY) license (http:// creativecommons.org/licenses/by/4.0/). 